\title{
In Vitro Study of Retentive Properties of Different Overdenture Attachment Systems On Straight and Divergent Dental Implants
}

Khalid Abdullaziz Azzouz

Follow this and additional works at: https://researchrepository.wvu.edu/etd

\section{Recommended Citation}

Azzouz, Khalid Abdullaziz, "In Vitro Study of Retentive Properties of Different Overdenture Attachment Systems On Straight and Divergent Dental Implants" (2017). Graduate Theses, Dissertations, and Problem Reports. 5135.

https://researchrepository.wvu.edu/etd/5135

This Thesis is protected by copyright and/or related rights. It has been brought to you by the The Research Repository @ WVU with permission from the rights-holder(s). You are free to use this Thesis in any way that is permitted by the copyright and related rights legislation that applies to your use. For other uses you must obtain permission from the rights-holder(s) directly, unless additional rights are indicated by a Creative Commons license in the record and/ or on the work itself. This Thesis has been accepted for inclusion in WVU Graduate Theses, Dissertations, and Problem Reports collection by an authorized administrator of The Research Repository @ WVU. For more information, please contact researchrepository@mail.wvu.edu. 


\title{
In Vitro Study of Retentive Properties of Different Overdenture Attachment Systems On Straight and Divergent Dental Implants \\ Khalid Abdullaziz Azzouz, D.D.S.
}

Thesis submitted to the

\author{
School of Dentistry \\ At West Virginia University \\ In partial fulfillment of the requirements \\ For the degree of \\ Master of Science \\ In \\ Prosthodontics
}

Matthew S. Bryington, D.M.D., M.S. (Chair)

Bryan D. Dye, D.D.S., M.S., F.A.C.P

Bryan Weaver, D.D.S., M.D.

Department of Restorative Dentistry

Morgantown, West Virginia

2017

Keywords: Locator R-TX; Locator; GPS; Implant; Attachment; Overdenture; Retention; Angled; Zest Anchors; Implant Direct

Copyright 2017 Khalid A. Azzouz 


\begin{abstract}
In Vitro Study of Retentive Properties of Different Overdenture Attachment Systems On Straight and Divergent Dental Implants

Khalid Abdullaziz Azzouz, D.D.S
\end{abstract}

Objectives: To evaluate the retention of Locator R-TX (ZEST Anchors LLC, Escondido, CA USA), Locator (ZEST Anchors LLC, Escondido, CA USA) and GPS (Implant Direct Sybron International, LLC, California, USA) dental implant attachment systems on parallel and divergent implants after sixteen months of simulated cyclic wear.

Methods: 30 acrylic blocks representing mandibular arches were used. Two Locator R-TX, two Locator, or two GPS abutment analogs were placed parallel or with 10 degrees of divergence in each block. The associated housings were picked up in corresponding acrylic blocks with clear Orthodontic resin (Dentsply GAC, Islandia, NY USA). The black processing liners in each housing were replaced with either low retentive or $1.5 \mathrm{lb}$ retentive elements. An eyebolt was attached to each block so it could be attached to an INSTRON 5565 Universal Testing Machine (Instron, Northwood, MA USA). The acrylic blocks were repeatedly separated and reattached by hand for 2000 pulls. The retentive force needed for dislodgement was measured at pull 500, 1000,1500 and 2000.

Results: The type of attachments (GPS, Locator, Locator R-TX) showed statistical significance. The number of pulls and the inter-implants angulation did not exhibit a statistical significance. The Locator attachment had 10.3 N more retention than the GPS and 3.6N more than the R-TX attachment.

Conclusions: After 2000 cycles of seating and unseating, the retention generated by Locator attachments was greater than other attachments and was not negatively affected by inter-implants angulation in the 0 to 10 degrees range. 


\section{DEDICATION}

I would like to dedicate this paper to my father, Abdullaziz Azzouz, who always been my role model and my motive to advance my knowledge and pursue a higher

education. For my mother, for her courage and outstanding care and guidance. For my wife, her sympathy and endless support during my postgraduate education. 


\section{ACKNOWLEGEMENTS}

I would like to thank the following individuals for providing much needed guidance during my postdoctoral training:

Dr. Matthew S. Bryington, for the knowledge, support and for being the best mentor anyone can ask for in advanced education.

Dr. Bryan D. Dye, Thank you for endless support, your knowledge and expertise in the field of the Prosthodontics. You are the best leader I have ever had.

Dr. Bryan Weaver, for the courses that I had with you and for the guidance for those complex cases I had with Oral surgery department.

Dr. Michael Bagby, Thank you for your instructions, support and for providing me with the necessary equipment to complete my project.

Dr. Christopher Wine, thank you for the initial planning of this project and for the hard work that you had to do to make it successful.

Dr. Gerald Hobbs, Thank you for your statistical expertise. 


\section{TABLE OF CONTENTS}

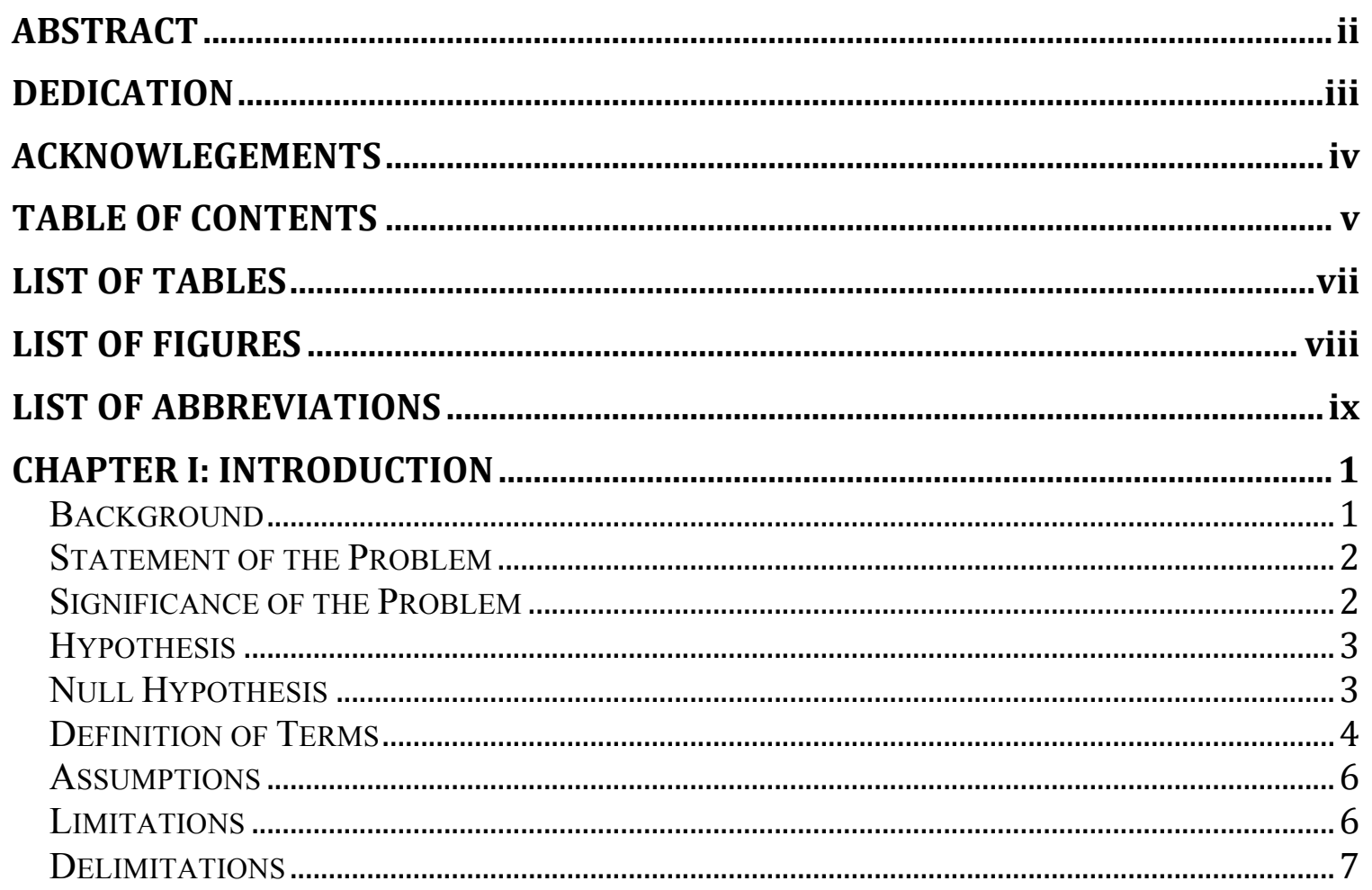

CHAPTER II: LITERATURE REVIEW ................................................................. 8

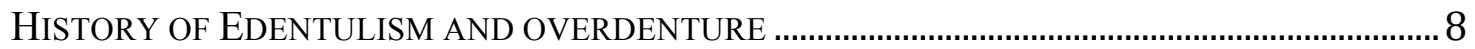

DENTAL IMPLANT UTILIZATION .......................................... ERROR! BOOKMARK NOT DEFINED.

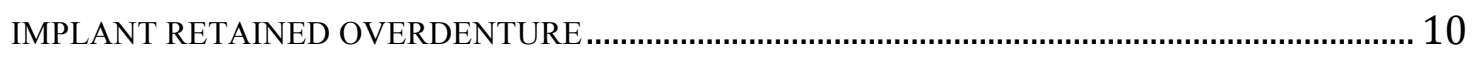

ATTACHMENT SYSTEMS FOR IMPLANT RETAINED OVERDENTURE …................................... 11

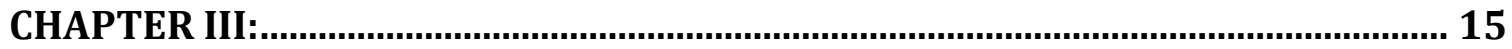

MATERIALS AND METHODS

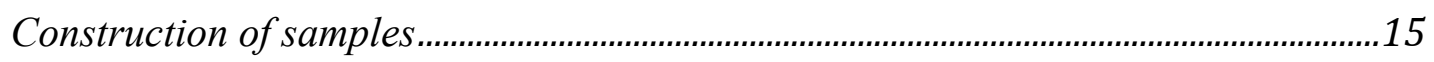

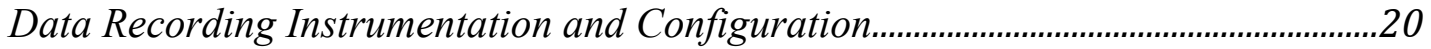

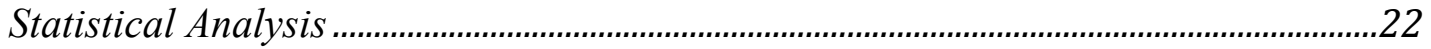

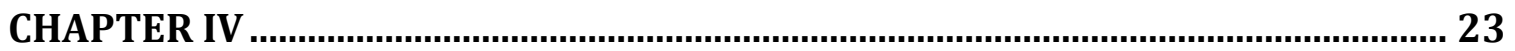

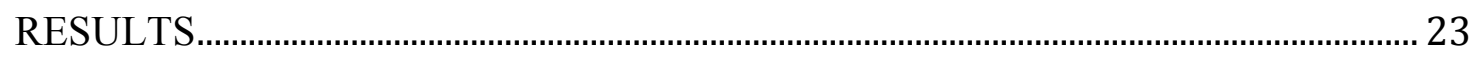

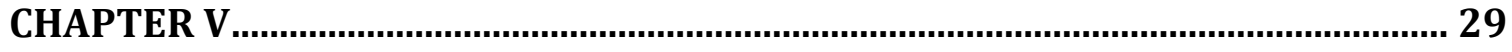

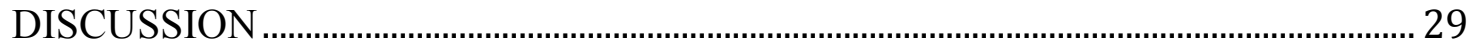

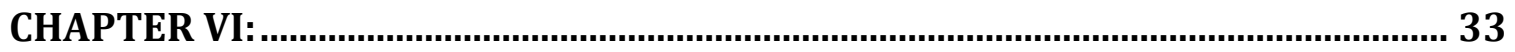

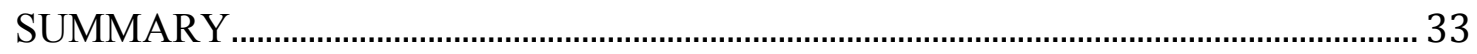

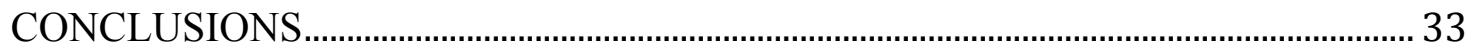




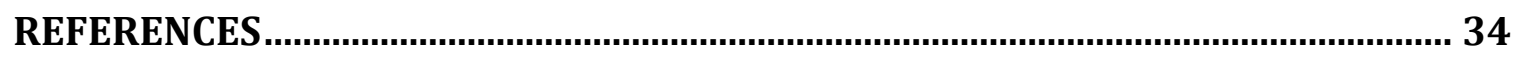

CURRICULUM VITAE ........................................................................................... 42 


\section{LIST OF TABLES}

Table 1. Means force for dislodgment of all sample groups and standard deviation Table 2. Mixed Effects ANOVA.

Table 3. Least Squares Means by type of Attachment.

Table 4. Least Squares Means by number of pulls.

Table 5. Least Squares Means by inter-implants angulation.

Table 6. Tukey-Kramer HSD defining significant differences within the type of the attachment.

Table 7. The initial and final retention for the sample groups. 


\section{LIST OF FIGURES}

Figure 1. Acrylic rod cut into blocks

Figure 2. Positioning jig with acrylic block positioned for drilling

Figure 3. Depth gauge locked for consecutive drilling at the same depth

Figure 4. Drill table set for 10 degress divergence holes

Figure 5. R-TX analogs secured in their respective blocks

Figure 6. R-TX analogs housings picked up in the upper blocks

Figure 7. A- Eyebolt placed, B- Finished sample

Figure 8. INSTRON 5565 Universal Testing Machine

Figure 9. Six sample groups

Figure 10A. Means force of dislodgment of GPS sample group

Figure 10B. Means force of dislodgment of LOCATOR sample group

Figure 10C. Means force of dislodgment of locator R-TX sample group

Figure 11. Means force for dislodgment of all sample groups 


\section{LIST OF ABBREVIATIONS}

PMMA- Polymethyl methacrylate

CAD/CAM- Computer aided design, computer assisted manufacturing

FDP- Fixed Dental Prosthesis

RPD- Removable partial denture

OD- Overdenture

IOD- Implant supported overdenture

ADA- American Dental Association 


\section{CHAPTER I: INTRODUCTION}

\section{Background}

Despite the advancements in dental diagnosis, treatment, and materials, the number of edentulous patients is still high. It is evident that tooth loss initiates a cascade of alveolar bone loss, irrespective of the over-all health of the skeleton. Regardless of the rate and pattern of bone loss, it usually occurs in the anterior areas more than the posterior areas of the jaws, and more in the mandible when compared with the maxilla. Thus, it is more critical to maintain the mandibular anterior teeth to retain alveolar bone.

A conventional complete mandibular denture is less favorable than a complete maxillary denture in terms of discomfort during mastication, as well as insufficient stability and retention of the denture due to impaired load-bearing capacity. However, the use of 2 implants to retain a denture significantly improves the prognosis of mandibular edentulism. In 2002, the McGill consensus statement on overdentures was released stating that the "Mandibular Two-Implant Overdenture as Minimum Standard of Care for Edentulous Patients". 1,2

An implant-retained overdenture requires more treatment planning than a conventional complete denture. One of the most important considerations in fabricating a mandibular overdenture is to ensure sufficient space for the prosthetic components of the implant attachment system. This can be achieved by three-dimensional analysis of that space, with consideration for the required dimensions of the denture base, position of denture teeth, implant location and angulation, and the attachment system that will be used. Inadequate space for prosthetic components can result in an over contoured prosthesis, excessive occlusal vertical dimension, fractured teeth adjacent to the attachments, attachments separating from the denture, fracture of the prosthesis, and overall patient dissatisfaction. ${ }^{3}$ 


\section{Statement of the Problem}

Does the type of overdenture attachment system used and the angulation of dental implants have an affect on the retention of a mandibular overdenture?

\section{Significance of the Problem}

According to the McGill Consensus Statement on overdentures, ${ }^{1}$ the two implant overdenture should become the minimal standard of care for treatment of the edentulous mandible. Overdentures can be attached to the implants with a variety of attachment systems. Some clinicians prefer splinted attachments such as Hader or Dolder bars while others prefer unsplinted attachments such as Locators, ERAs, magnets and ball anchors. The selection factors of attachment systems are the amount of space available, maintenance requirements, and patient ability to maintain good oral hygiene, interimplants angulation, dentists' preference, and the degree of retention required. In 2001, a literature review by Sadowsky ${ }^{2}$ considered the use of two solitary stud attachments to retain mandibular implant-retained overdenture as they appear to be less costly, less technique sensitive and require less space compared to the bar attachment.

Maintenance of the two attachment types is controversial. Some studies suggest that a bar attachment requires less maintenance ${ }^{4,5}$ whereas others suggest the opposite. ${ }^{3,6,7}$ Additionally, proper hygiene around the bar is more difficult than for individual attachments. Regardless of the attachment system used, it inevitably wears during function, leading to loss of retention and many studies attributed that to the amount of inter-implants angulation, as divergent implant angulations may complicate or prevent successful mating of attachment designs, producing accelerated attachment wear and path of insertion problems. The locator attachment system (ZEST Anchors LLC, Escondido, CA USA) with its lowest profile becomes popular among the stud attachments. Recently, the same manufacturer introduced Locator R-TX with 50\% more pivoting capability to accommodate inter-implants angulation up to 60 degrees. The GPS attachment system (Implant Direct Sybron International, LLC, California, USA) that is 
similar to Locator was introduced with claims of better performance on implants with 10 degrees of divergence. Based on the manufacturer's recommendation of three attachment systems used in this study, the 10 degrees inter-implants divergence is within the tolerance of these systems.

\section{Hypothesis}

There will be a significant difference in the retention of the Locator R-TX, Locator, and GPS attachment systems on parallel and divergent implants.

\section{Null Hypothesis}

There will be no significant difference in the retention of the Locator R-TX, Locator and GPS attachment systems on parallel and divergent implants. 


\section{Definition of Terms}

Dental prosthesis: an artificial replacement (prosthesis) of one or more teeth (up to the entire dentition in either arch) and associated dental/alveolar structures. Dental prostheses usually are subcategorized as either fixed dental prostheses or removable dental prostheses. $^{8}$

Denture: an artificial substitute for missing natural teeth and adjacent tissues. ${ }^{8}$

Denture retention: 1) the resistance in the movement of a denture away from its tissue foundation especially in a vertical direction, 2) a quality of a denture that holds it to the tissue foundation and/or abutment teeth. ${ }^{8}$

Wear: has been defined as "loss of material from a surface caused by mechanical action alone or through a combination of chemical and mechanical actions". 9

Overdenture: any removable dental prosthesis that covers and rests on one or more remaining natural teeth, the roots of natural teeth, and/or dental implants; a dental prosthesis that covers and is partially supported by natural teeth, natural tooth roots, and/or dental implants- called also overlay denture, overlay prosthesis, superimposed prosthesis. $^{8}$

Dental implant: a prosthetic device made of alloplastic material(s) implanted into the oral tissues beneath the mucosal or/and periosteal layer, and on/or within the bone to provide retention and support for a fixed or removable dental prosthesis; a substance that is placed into or/and upon the jaw bone to support a fixed or removable dental prosthesis. $^{8}$

Implant dentistry: the selection, planning, development, placement, and maintenance of restoration(s) using dental implants. ${ }^{8}$ 
Osseointegration: the apparent direct attachment or connection of osseous tissue to an inert, alloplastic material without intervening connective tissue. ${ }^{8}$

Implant denture: a denture is not an implantable device. Dental prostheses (fixed dental prostheses, removable dental prostheses) as well as maxillofacial prostheses can be supported and retained in part or whole by dental implants. Terminology to assist in describing the means of retention, support and dental materials should be limited to concatenation of three and no more than four adjectives to provide clarity. ${ }^{8}$

Attachment: 1) a mechanical device for the fixation, retention, and stabilization of prosthesis. 2) A retainer consisting of a metal receptacle and a closely fitting part; the former (the female \{matrix \} component) is usually contained within the normal or expanded contours of the crown of the abutment tooth and the latter (the male \{patrix component), is attached to a pontic or the denture framework. ${ }^{8}$

Dental implant abutment: the portion of a dental implant that serves to support and/or retain any fixed or removable dental prosthesis. Usage: frequently dental implant abutments, especially those used with endosteal dental implants, are changed to alter abutment design or use before a definitive dental prosthesis is fabricated. Such a preliminary abutment is termed an interim (dental implant) abutment. The abutment chosen to sup-port the definitive prosthesis is termed a definitive (dental implant) abutment. Dental implant abutments frequently are described by their form (i.e., cylindrical, barrel), material (i.e., ceramic, titanium, zirconia ceramic), or special design factors (i.e., internal hex lock, external hex lock, spline). ${ }^{8}$

Abutment analog: a replica of the superior portion of a dental implant. Usually used to provide an exact form of the dental implant abutment within the dental laboratory during fabrication of prosthesis supported in part or whole by the dental implant. ${ }^{8}$ 


\section{Assumptions}

1. It is assumed that all Acrylic blocks are homogenous, structurally identical, and cut into the same measurements.

2. It is assumed that each attachment type and corresponding housings are consistent with the manufacturer's defined dimensions and specifications.

3. It is assumed that each attachment type and corresponding housings are rigidly attached to the acrylic blocks.

\section{Limitations}

1. The laboratory offers an environment in which a single variable can be studied in isolation, including those which may be difficult or impossible to measure in the clinical situation. Factors thought to contribute to increased overdenture attachment wear in vivo, but not replicated in this experiment, and therefore, considered a limitation of this laboratory study, include: complex overdenture displacements during masticatory function, insertion of prostheses along variable paths of insertion, variations in implant alignment, presence of saliva, variation in the conditions of the oral environment, and effect of denture cleansing products. ${ }^{10,11,9,12,13}$

2. Abutment analogs have been used instead of using the actual abutments to test the retentive properties of these attachment systems. 


\section{Delimitations}

1. To better simulate deviations from ideal the implants were either positioned in parallel or had an inter-implants divergence of 10 degrees.

2. Attachments seated and unseated by hand, could influence the wear patterns of the liners in more of a clinical relevant manner than seating and unseating by machine.

3. The number of cyclic seating and unseating was limited to 2000 pulls.

4. Only minimally retentive inserts were used in this study. 


\section{Chapter II: LITERATURE REVIEW}

\section{History of Edentulism and Overdenture}

Edentulism is a significant health problem that affects millions of people around the world. The variation in anatomy, physiology, and the comorbidities associated with this problem created many diagnostic, planning, and treatment challenges for the clinicians since the beginning of this profession as well as the patients. Hunter et. al. ${ }^{14}$ advocated dental extractions as a cure for a variety of dental and medical problems and referred to restorative dentistry as "mausoleums of gold over a mass of sepsis.". ${ }^{14}$ The art of replacing missing teeth with dentures began as early as 700 B.C. with the Etruscans, who designed teeth made from Ivory and bone. In 1795, John Greenwood made President George Washington's dentures; which were constructed of hippopotamus ivory, cow teeth, elephant tusk, natural teeth, and gold. Despite Greenwood's efforts, dentistry for decades has had limited success at replacing teeth until reliable denture materials were developed. ${ }^{14}$

In the 1850's Claudius Ash and Seymour White developed porcelain teeth. Later, Nelson Goodyear discovered a hardened rubber material called "Vulcanite" and he used it as a base for porcelain teeth to creates serviceable dentures. ${ }^{14}$ Nowadays, resin composite, Polymethyl methacrylate (PMMA) teeth and denture bases are very popular. Regardless of the materials and methods used to construct complete dentures, the principles that denture retention relies on are the same; adhesion, cohesion, atmospheric pressure, the dentist should consider these principles in order to meet the patient expectations.

In 1861, Butler, Roberts and Hays presented the concept of overdentures at the world dental congress. ${ }^{14}$ By the 1960s, there was sufficient information to launch the concept of overdentures as a viable treatment modality. ${ }^{15,16,17,18}$ 
Dentists were already successful at making complete dentures. They were also aware of the alveolar bone loss that followed tooth loss. The possibility of intentionally leaving roots under dentures began to receive consideration as a means to prevent alveolar bone loss. In 1970 during the annual meeting of the ADA, Charles Bolender and his study club presented 12 years of case reports that outlined the current concepts of overdentures as an alternative treatment modality. ${ }^{14}$ The landmark articles that described simplified overdenture treatments were published by Morrow et. al. ${ }^{19}$ and Lord and Teel. ${ }^{20}$ Later textbooks described the various principles, concepts, and practices specific to overdenture therapy. ${ }^{14}$

\section{Dental Implant Utilization}

Within the dental profession, the use of dental implants has become one of the most significant treatment modalities for edentulism. The idea began about 4000 years ago, with the Chinese, who used carved bamboo sticks and drove them into the bone. About 2000 years ago, the Egyptians used precious metals as implants and the Incans took pieces of seashells and tapped them into the jawbone. In 1809, Maggiolo introduced a gold root form implant, while in 1913 Greenfield introduced a two-piece basket implant. $^{21}$

A direct bone-implant interface to titanium was initially called bone fusing and was first reported in 1940 by Bothe and coworkers. In 1948 a turn toward modern implantology was taken by Al Strock, who invented a series of two-stage implants that were made from cobalt chromium molybdenum in which the abutment was attached after healing. He called the interface between bone and implant ankylosis. ${ }^{21}$

In 1952 the Swedish Orthopedic surgeon Per-Ingvar Brånemark, discovered the process of osseointegration while he was studying bone healing and regeneration. 
He learned this when he couldn't remove a titanium chamber that had been previously placed into a rabbit femur. In 1965 he placed his first fixture into the patient who died in 2006 with the implant still in function.

In 1982, the Brånemark implant philosophy was first introduced to the United States. Research focused on the bone-implant interface and biological considerations. Initially these studies received little interest, despite the evidence that the use of dental implants could provide predictable results. ${ }^{22,23}$

The dental implant marketplace has expanded substantially since 1982, bringing innovation to the industry and increasing the number of available treatment options. The basic language for endosteal implants was developed by Misch and Misch in 1992. In 2000, the U.S. market alone had to choose from more than 1300 different implant designs and 1500 abutments in various materials, shapes, sizes, diameters, lengths, surfaces, and connections. This common language was necessary for the communication between the practitioners and dental labs. ${ }^{21}$

\section{Implant Retained Overdenture}

Brånemark demonstrated that the fixed reconstruction of mandibular implants offered a predictable method to rehabilitate maladaptive edentulous patients. ${ }^{24}$ Soon after, it was realized that implant-retained overdentures offered a simpler, cheaper, and equally successful prosthetic solution. ${ }^{25,26}$ Implant-retained overdentures have since been shown to provide improved masticatory function, patient satisfaction, and quality of life compared to conventional complete dentures, particularly in maladaptive complete denture patients. ${ }^{27,28}$

Studies have shown an average of $4 \mathrm{~mm}$ of bone resorption occurs during the first year after tooth loss and decreases to $0.5 \mathrm{~mm}$ per year thereafter. ${ }^{29}$ Therefore, dental implants should be considered as an important treatment modality in the mandible to aid with denture stability. In 2002, the McGill consensus statement on overdentures 
was released, stating that the "Mandibular Two-Implant Overdenture as Minimum Standard of Care for Edentulous Patients". ${ }^{1,2}$ Schwartz-Arad et. al. ${ }^{30}$ found that $70 \%$ of their patients with implant-supported overdentures lost less than $0.2 \mathrm{~mm}$ bone in the first year.

The cumulative success rate of all implant-retained overdentures is $95.4 \%$, with implant-retained overdentures having a slightly higher success rate in the mandible than in the maxilla. ${ }^{29}$ Treatment considerations for implant overdentures on the maxilla appear to be different than for those on the mandible. Atrophy of the edentulous jaws may limit implant placement on the maxilla, where as in the mandible, the reduction of residual ridge often leaves a significant depth and width of basal bone anteriorly to accommodate implants. Mericske-Stern et. al. reported 97\% implant survival with two implants (splinted or unsplinted), irrespective of keratinized tissue or duration of edentulism. Jemt et. al. reported 100\% cumulative success rate for overdentures supported by two implants and the mean marginal bone loss was $0.5 \mathrm{~mm}$ during a 5 -year period. ${ }^{25}$

\section{Attachment Systems for Implant Retained Overdenture}

The overdentures can be attached to the implants with a variety of attachment systems. Some clinicians prefer splinted attachments such as bars, while others prefer unsplinted (stud) attachments such as Locators, GPS, ERA, magnets and ball anchors. The selection factors of attachment systems are the amount of space available, maintenance requirements, and patient ability to maintain good oral hygiene, interimplants angulation, and the degree of retention required.

Caldwell ${ }^{31}$ studied the adhesive nature of foods and calculated that a mandibular distal extension removable partial denture with acrylic resin teeth would require a retaining force of 15 to $20 \mathrm{~N}$, when sticky toffee was masticated. This force would be reduced to about $10 \mathrm{~N}$ for normal foods. It would therefore be logical to assume that an attachment would require a retentive capacity of 10 to $20 \mathrm{~N}$ to maintain the denture in 
position. ${ }^{32}$ In another in vitro study, ${ }^{33}$ the maximum dislodging forces ranged between 27 and $37 \mathrm{~N}$. On the basis of these findings, the authors concluded that the clinician might be able to make empirical decisions regarding attachment selection, depending on the amount of retention desired and the specific clinical situation. ${ }^{34}$

Gamborena et. al. ${ }^{35}$ investigated the retention of 4 different color-coded ERA attachments (Sterngold Dental; Attleboro, MA USA) prior to and after various levels of fatigue loading. After a simulated 3 years of attachment placement and removal, an overall retention loss ranged from $80 \%$ to $85 \%$. The retentive forces and wear of commercially available attachments of four implant systems have also been described. ${ }^{36}$ After 15,000 cycles, most of the attachments showed little loss of retention compared to the initial retentive forces. It was concluded that conventional fatigue tests with applied axial loads do not simulate clinical fatigue adequately.

Stewart and Edwards ${ }^{37}$ tested the wear and the retentive properties of five precision attachments, and concluded that each attachment behaved differently. One attachment, exhibited an increase of retentive forces similar to those that occurred in the current study. An increase in the retention in the first 100-120 cycles of each sample was demonstrated, and then the retention decreased gradually. The authors suggested that the initial increase could be due to an increase in surface roughness after initial wear occurred.

It has been a point of controversy concerning the maintenance of different attachment types. Some studies suggest that a bar attachment requires less maintenance 4,5 whereas others suggest the opposite regarding unsplinted attachments. ${ }^{3,6,7}$ Naert et. $a l .{ }^{38}$ in a 5-year prospective study concluded OD connection type did not influence the peri-implant status and the highest retention was among the bar group and the lowest in the magnet group. The ball group was more stable over time, and prosthetic complications were less in the bar group. Sadowsky ${ }^{39}$ concluded when two implants were used in the anterior mandible to retain an overdenture, solitary ball attachments appeared to be less costly, less technique sensitive, and more accommodating of tapered arches. However, ball attachments seemed to be less retentive than the bar design. Also, 
overdentures retained by 2 implants in the anterior mandible appeared to demonstrate a higher burden of maintenance during the first year than in subsequent years.

Nedir et. al. ${ }^{40}$ compared different attachments. He found that bar-retained overdentures experienced fewer complications than ball-retained overdentures $(42.9 \%$ versus $77.5 \%$ ). At 3 years, the incident-free prosthesis rate was $71.4 \%$ for the bar-retained group and $37.5 \%$ for the ball-retained group. Controversy persists as to whether the ball or bar design requires more maintenance. Regardless of the attachment system used, it inevitably wears during function, leading to loss of retention. Many studies attributed that to the amount of inter-implants angulation, as divergent implant angulations may complicate or prevent successful mating of attachment designs, producing accelerated attachment wear and path of insertion problems.

In systematic reviews comparing implant overdentures retained using a range of attachment mechanisms, ${ }^{11,41,42}$ it was concluded that attachment type has no effect on implant survival, ${ }^{41,43}$ long-term peri-implant tissue health, ${ }^{11,43}$ patient satisfaction (with the exception of magnets), ${ }^{11,43}$ or the prevalence of prosthetic complications. ${ }^{42}$ The most common maintenance requirement of overdenture attachments has been found to be the renewal or reactivation of the retentive element. Stud attachments require more frequent maintenance than bars in this respect. ${ }^{11,43,42}$

Overdenture attachments may occupy a substantial amount of available prosthetic space, and predictable restoration is best achieved by planning implant positions to allow the attachment to be surrounded by $2 \mathrm{~mm}$ of denture acrylic. ${ }^{44}$ Lack of respect for space requirements may encourage bulk fracture of the acrylic denture base or compromise prosthetic tooth positioning, potentially causing esthetic or phonetic problems. ${ }^{44}$ Stud attachments generally require less room than bar designs. Additionally, proper hygiene around the bar is more difficult than for individual attachments.

The locator attachment system (ZEST Anchors LLC, Escondido, CA USA) has the lowest profile among the stud attachments, and quickly gained widespread popularity since its introduction in 2001 due to its simplicity and modest space requirements. ${ }^{10}$ The 
Locator "female" matrix consists of a titanium nitride coated cylindrical abutment featuring internal and external undercuts. The "male" comprises a metallic housing into which interchangeable nylon patrices are inserted. ${ }^{10}$ A range of nylon inserts are available, color-coded according to retention and design. The manufacturer claims that a difference of 10 degrees can be tolerated between the path of insertion of the patrix insert and the central axis of the matrix abutment. The manufacturer therefore recommends their use where inter-implant angles are in the 0 to 20 degrees range. An "extended range" of color-coded inserts is recommended for use where inter-implant angles exceed 20 degrees.

In 2013, a system similar to the Locator called the GPS attachment system (Implant Direct Sybron International, LLC, California, USA) was introduced with claims of better performance on implants with 10 degrees of divergence. The company claimed the GPS Internal Liner retains $100 \%$ of its initial retention at 10 degrees angulation compared to Locator dual retention liners, which lose $27 \%$ of their initial retention, but soon the product was discontinued from the market. In 2016, Locator R-TX (ZEST Anchors LLC, Escondido, CA USA) was introduced to the market.

Locator R-TX is made from DuraTec Titanium Carbon Nitride for better wear resistance. Its geometrical design included dual narrow retentive surfaces for easier seating of the OD. With a manufacturer reported $50 \%$ more pivoting capability for interimplants angulation up to 60 degrees, it has been marketed as the successor to the Locator abutment. All concepts stated above are important considerations when determining which attachment system to use for the patient and since every patient is different and every complication requires extra time and cost to the patient. A design that offers better hygiene and requires the least maintenance should be considered. 


\section{Chapter III:}

\section{MATERIALS AND METHODS}

\section{Construction of Samples}

Following a protocol described by Wine et.al., ${ }^{45}$ an acrylic rod (Plastic-Craft Products, West Nyack, NY USA) was cut into 30 blocks measuring 1 inch x 1 inch x 1.5 inches (Figure 1). Blocks were divided into six sample groups; every group consisted of five samples. Each sample included a lower block that consisted of 2 analogs and an upper block contained the housings and eyebolt for attachment to the testing machine. The sample groups were divided as following: the first three sample groups were built with two parallel Locator R-TX analogs, two parallel Locator analogs and two parallel GPS analogs. The next three sample groups were made with two Locator R-TX analogs with 10 degrees of divergence, two Locator analogs with 10 degrees divergence and two GPS analogs with 10 degrees of divergence.

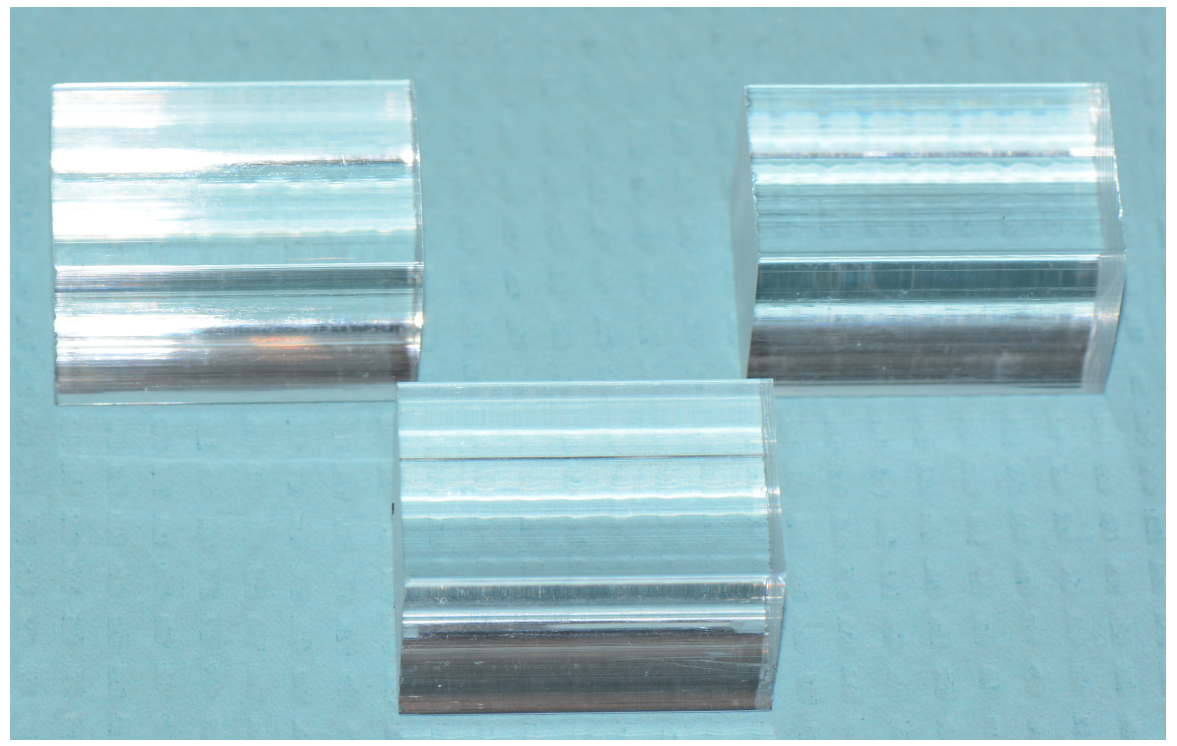

Figure 1. Acrylic rod cut into blocks. 
In order to stabilize the acrylic blocks to the table of a drill press and reposition them for consecutive drilling in the same spot, a jig was made utilizing a bench vise and metal gauge (Palmgren Naperville, IL, USA) (Figure 2). Blocks were marked to reference the position of the proposed analogs so they were $12 \mathrm{~mm}$ apart. The drill press table was set at 0 degrees and the jig was attached to the table. The first block was drilled at the reference point to a width slightly larger than a Locator R-TX analog and a depth that allow the analog head to be $2-3 \mathrm{~mm}$ above the acrylic. The depth gauge was locked and four more blocks were drilled for a total of five blocks. Next, the Jig was adjusted to allow for the drill to line up to the second reference point on the first block and stabilized (Figure 3).

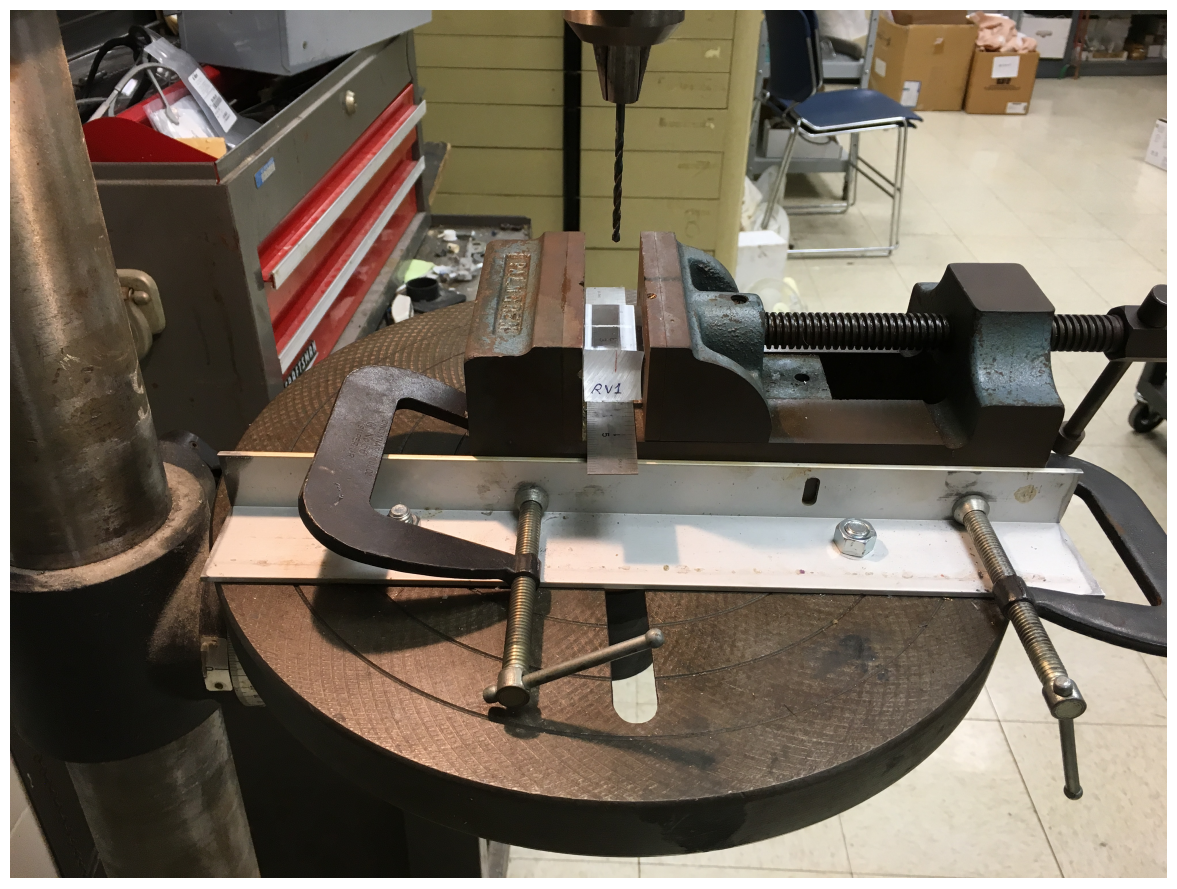

Figure 2. Positioning jig with acrylic block positioned for drilling. 


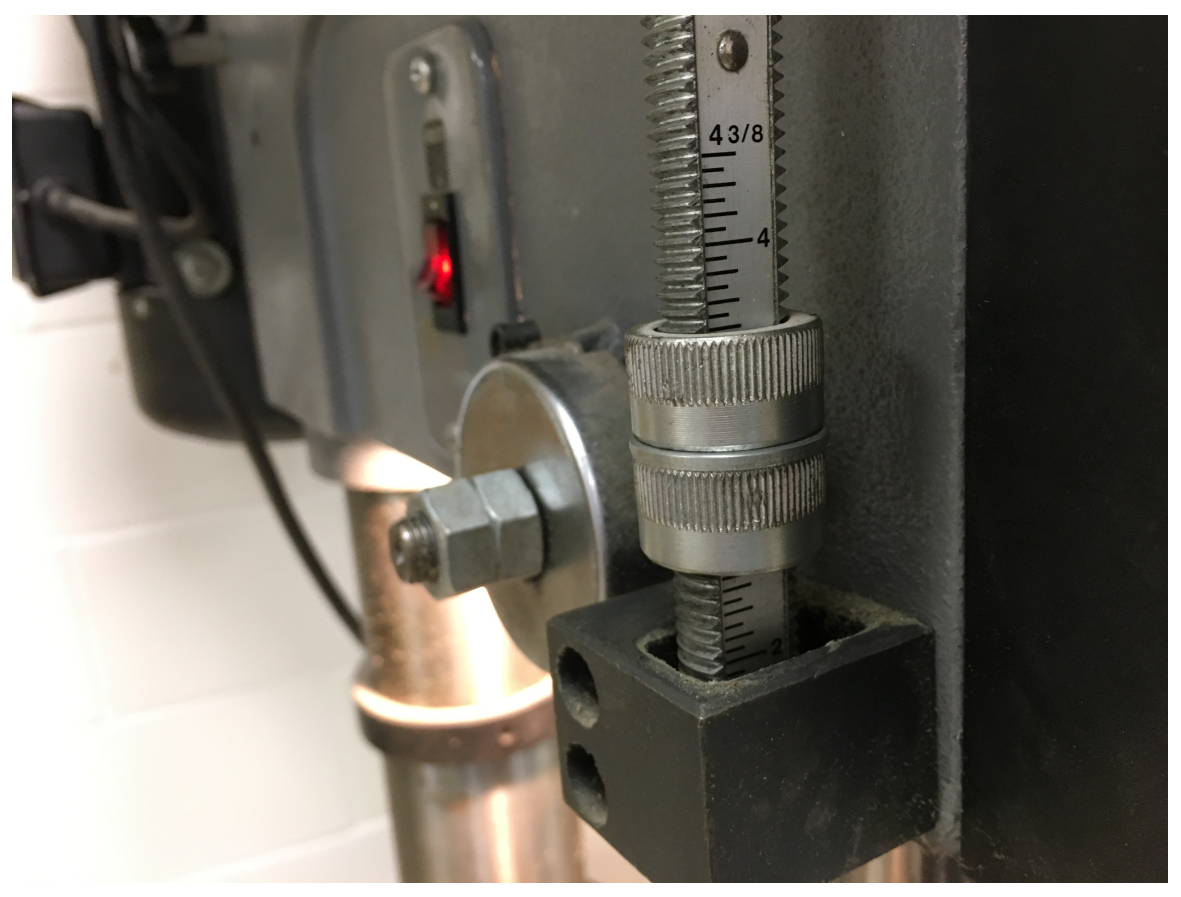

Figure 3. Depth gauge locked for consecutive drilling at the same depth.

The previous five Locator R-TX blocks were drilled producing the holes for the parallel Locator R-TX group. The drill press table was angled and locked at 5 degrees from the midline of the block to allow for the two holes to be drilled at a total of 10 degrees of divergence. Then, the previous procedure was repeated (Figure 4). Five blocks were drilled and the angled Locator R-TX group was made.

The drill press table was set at 0 degrees and the jig was repositioned and stabilized so the drill lined up with the marks that have been made in the center of the upper blocks and depth gauge was locked. Ten new upper blocks were drilled to allow for the attachment of an eyebolt. 


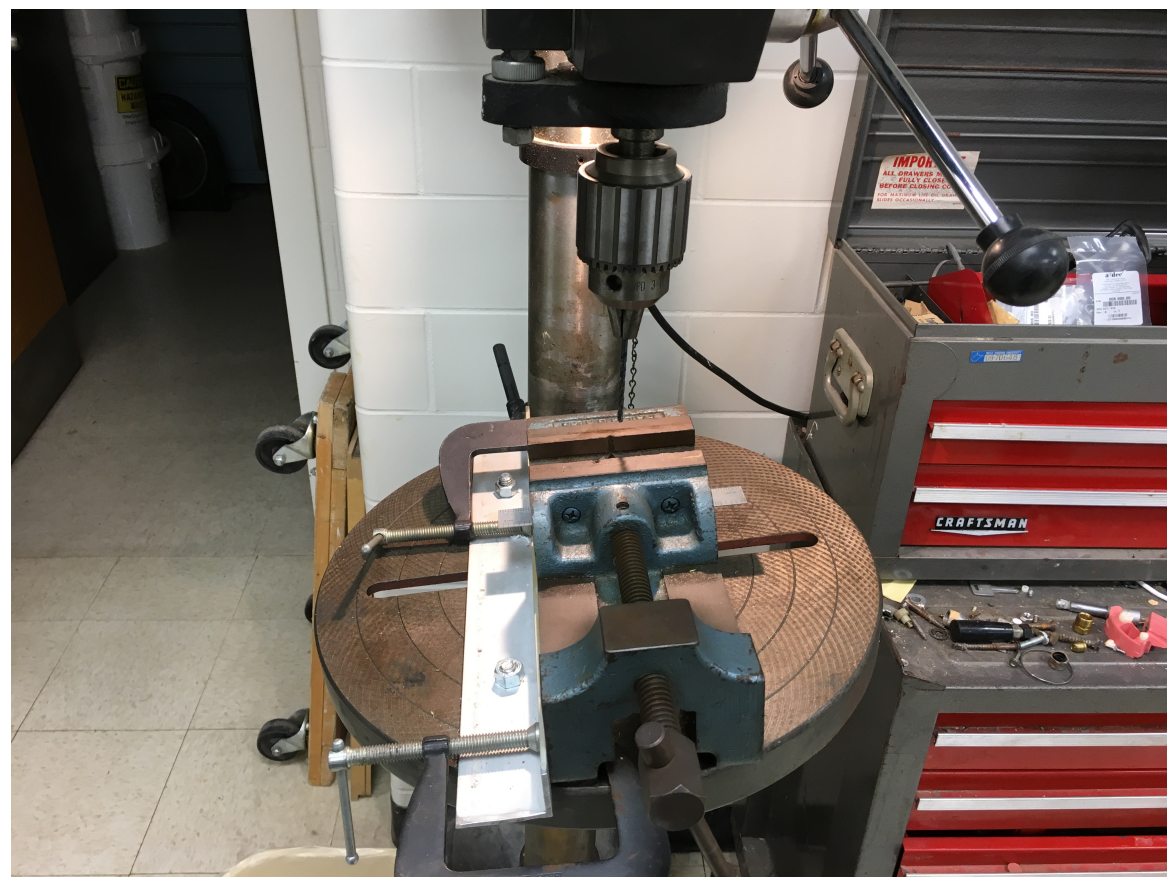

Figure 4. Drill table set for 10 degress divergence holes.

The abutment analogs were secured into their respective blocks with Integrity Multi.Cure (Dentsply Caulk, Milford, DE USA) (Figure 5). A space was made with hand piece and carbide burs to pick up the housings of the Locator R-TX system. The upper and lower block contact surfaces were painted with Orthodontic Resin Separator (Dentsply GAC, Islandia, NY USA) and block out O-rings and attachment housings were placed on the abutment analogs of their respective blocks. Clear orthodontic resin (Dentsply GAC, Islandia, NY USA) was mixed based on the manufacture recommendation and placed in the relief area of the upper blocks and then the upper blocks were seated on the lower corresponding blocks so the resin would be allowed to polymerize around the attachment housings (Figure 6). 


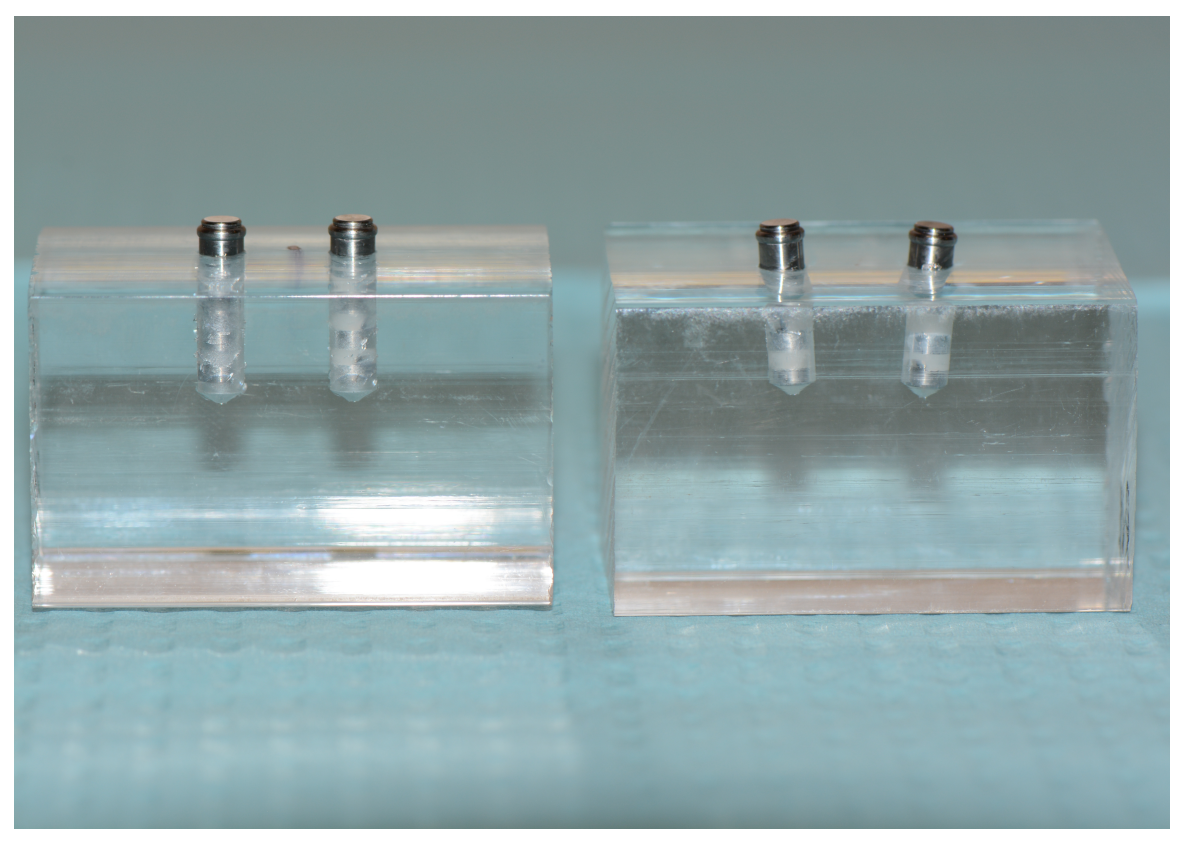

Figure 5. R-TX analogs secured in their respective blocks.

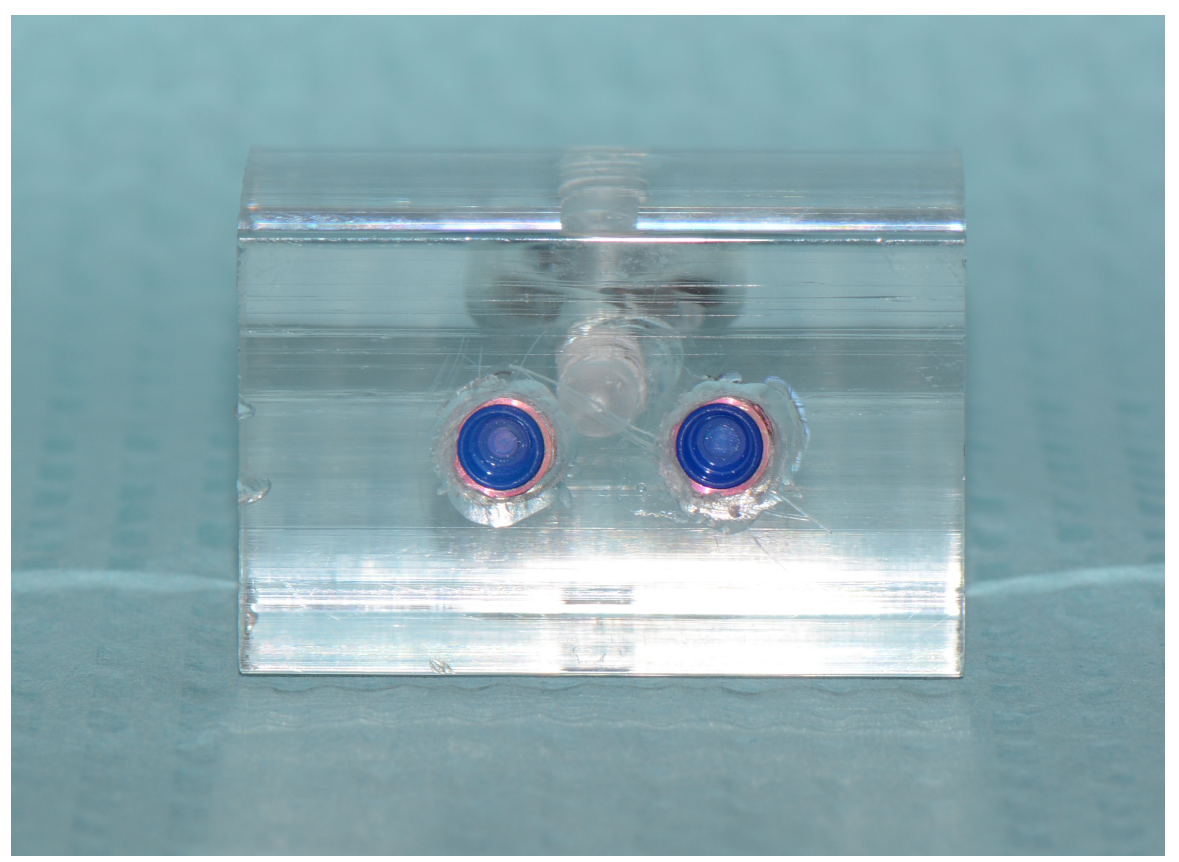

Figure 6. R-TX analogs housings picked up in the upper blocks. 
Once the resin was fully polymerized, the upper and lower blocks of each sample were marked and separated. An eyebolt was then screwed into the top of the upper block (Figure 7 - A and B). The black processing inserts were replaced with a blue (Low Retention) retentive inserts for all the housings.
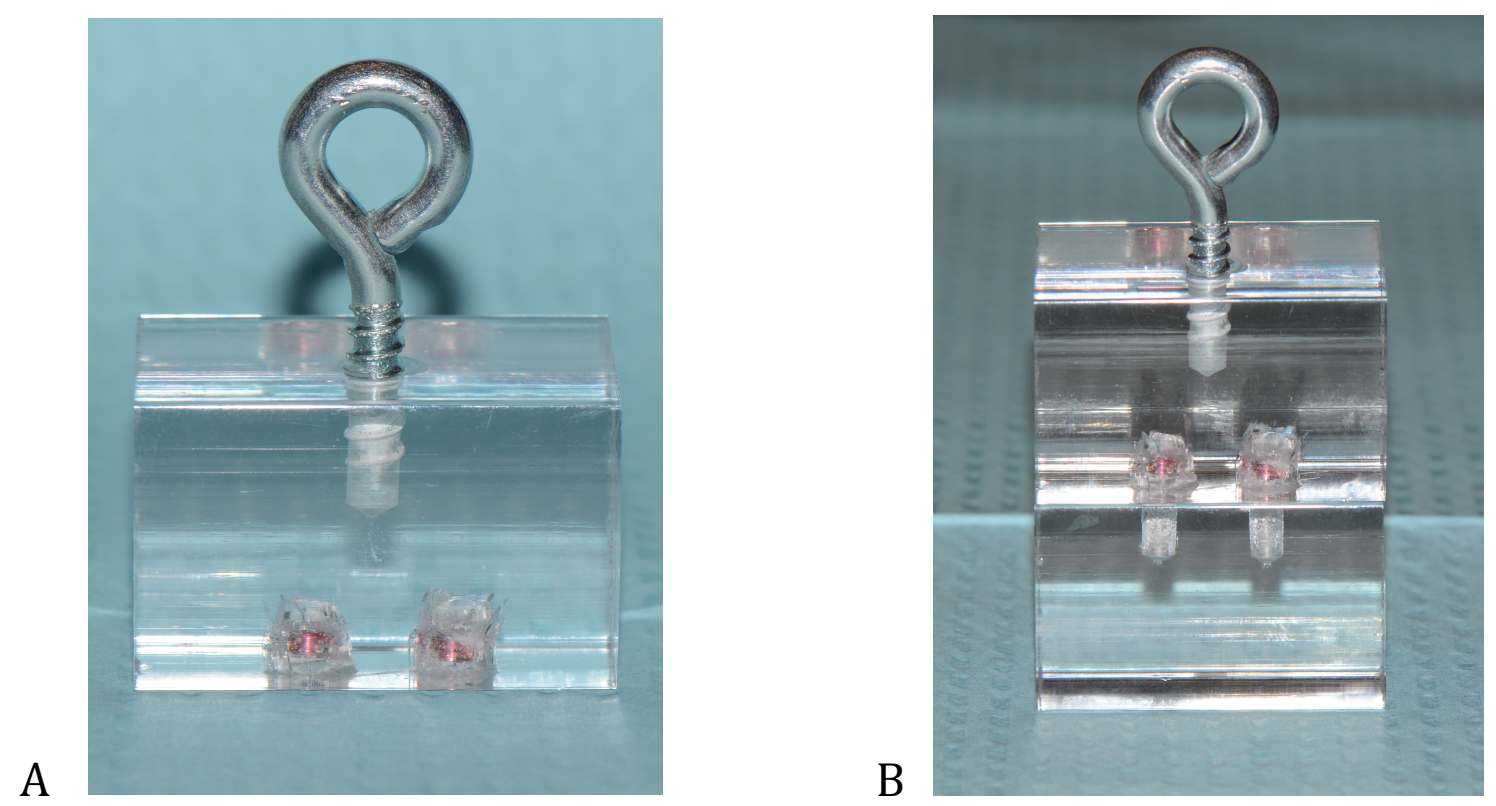

Figure 7. A- Eyebolt placed, B- Finished sample.

\section{Data Recording Instrumentation and Configuration}

To minimize the amount of errors and to standardize the position of Acrylic block on the testing machine, A Sil-tec (Ivoclar Vivadent Inc., Amherst, NY USA) putty index was made on the Instron vice so that each block could be repositioned and tightened in the same position for each test. A metal chain was fixed to the load cell of the INSTRON 5565 Universal Testing Machine (Instron, Northwood, MA USA). The bottom of the chain was attached to the eyebolt of the top block of each sample when it was tested (Figure 8). 


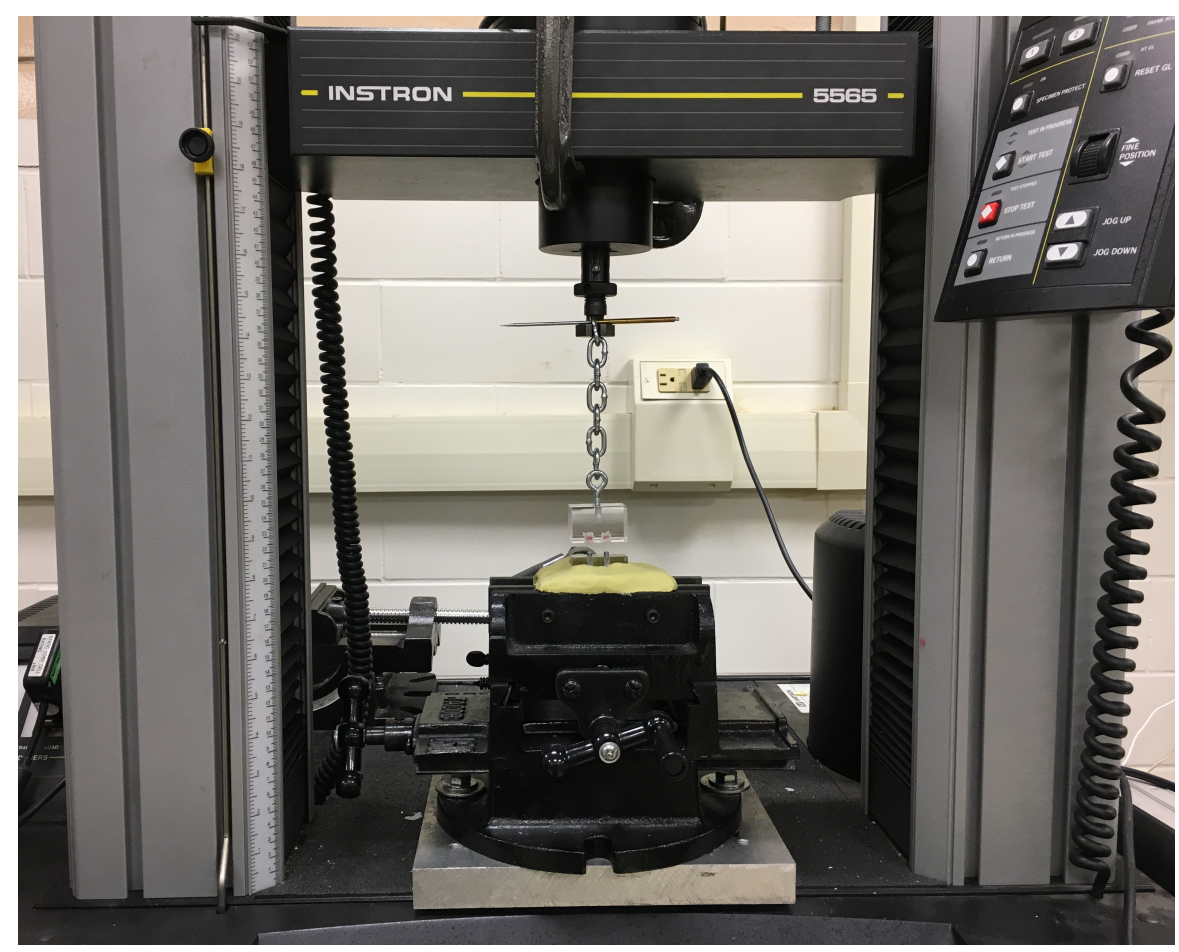

Figure 8. INSTRON 5565 Universal Testing Machine.

To simulate sixteen months of mandibular overdenture seating and unseating, it was determined to make 2000 seating or unseatings, referred from here on as a "pull" for each sample. All six groups (Figure 9) were separated and put together by hand except for the recorded pulls. The Instron Machine was connected to the sample block for pulls 500, 1000, 1500 and 2000. The Instron Machine was calibrated and the load of the machine was equalized for every sample. The blocks were separated at $50 \mathrm{~mm} / \mathrm{min}$. The force to dislodge the blocks was recorded. 


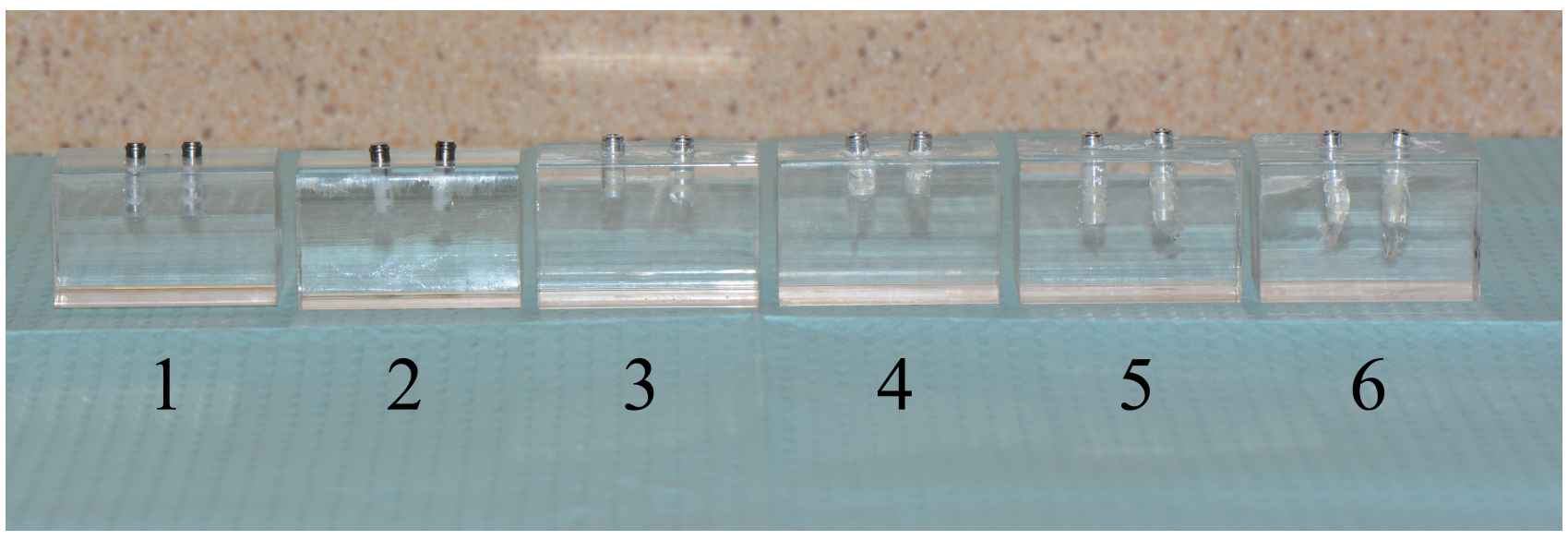

Figure 9. 1) parallel locators R-TX, 2) Locators R-TX with 10 degrees divergence, 3) parallel LOCATORs, 4) LOCATORs with 10 degrees of divergence, 5) parallel GPS, 6) GPS with 10 degrees of divergence.

\section{Statistical Analysis}

The data consists of dislodgment (retentive) forces measured in Newtons (N) and recorded for each sample in the 6 configurations at pulls 500, 1000, 1500 and 2000. The mean force for dislodgement and standard deviation was computed for each sample group and then plotted individually and as a group. An analysis of variance compared all the groups as a whole. When a test with random effects (Mixed Effects ANOVA) compared the interactions of the data, the only interaction that was significant was the attachment. Neither pull nor angulation were significant.

The averages were compared using mixed-effects ANOVA to define the variables' effect on loss of retention. The variables, which demonstrated significant differences, were further evaluated using a post-hoc Tukey-Kramer Honestly Significant Difference (Tukey-Kramer HSD) to assess differences between pairs of means. The statistic software used to evaluate the data was JMP Pro Version 12 (Cary, NC). 


\section{Chapter IV}

\section{RESULTS}

The retentive (dislodgement) forces were recorded for each sample in the 6 configurations at pulls 500,1000,1500, and 2000. The mean force of dislodgement and standard deviation for each pull of every sample group was plotted individually in (figure $10 \mathrm{~A}-\mathrm{C}$ ) and then as a group in (figure 11), (Table 1).

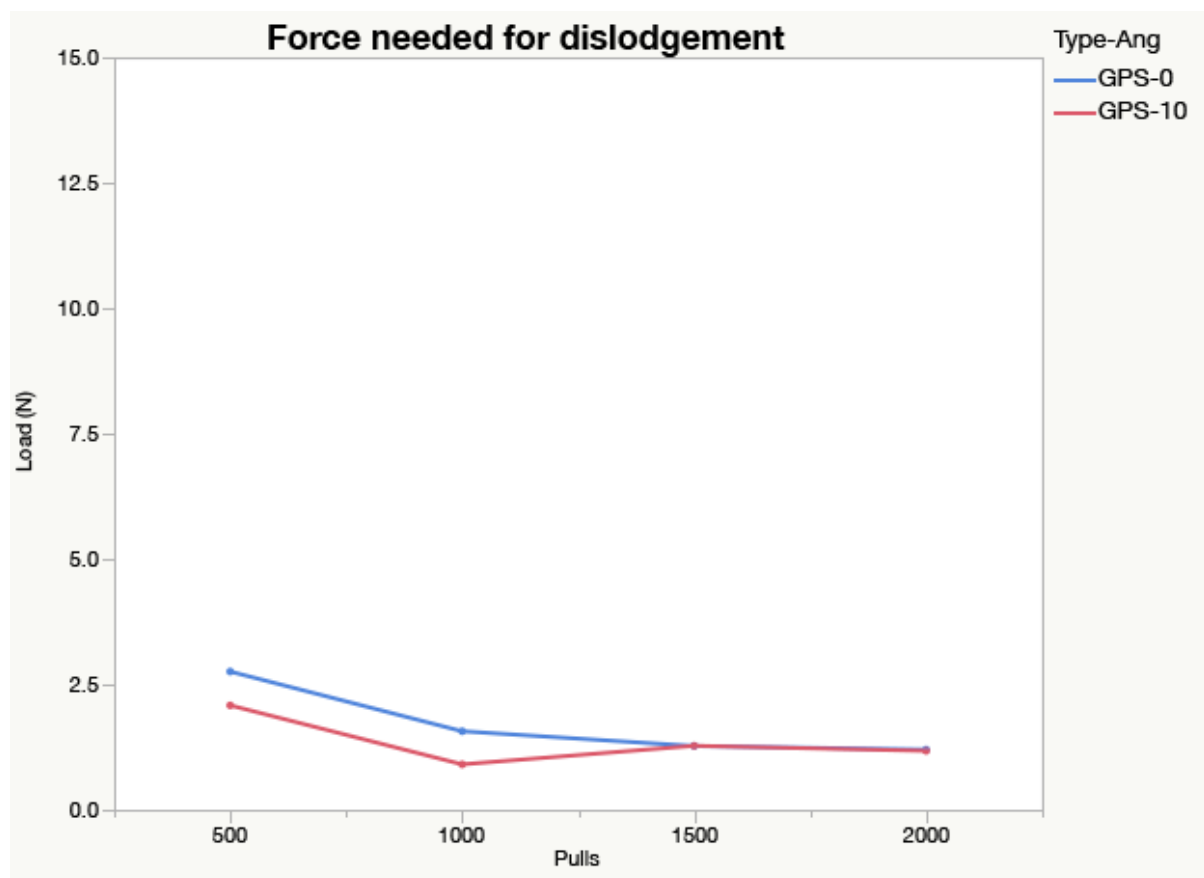

Figure 10-A. Means force of dislodgment of GPS sample group (JMP/Pro Ver12, SAS Inst. Inc., Cary, NC). 


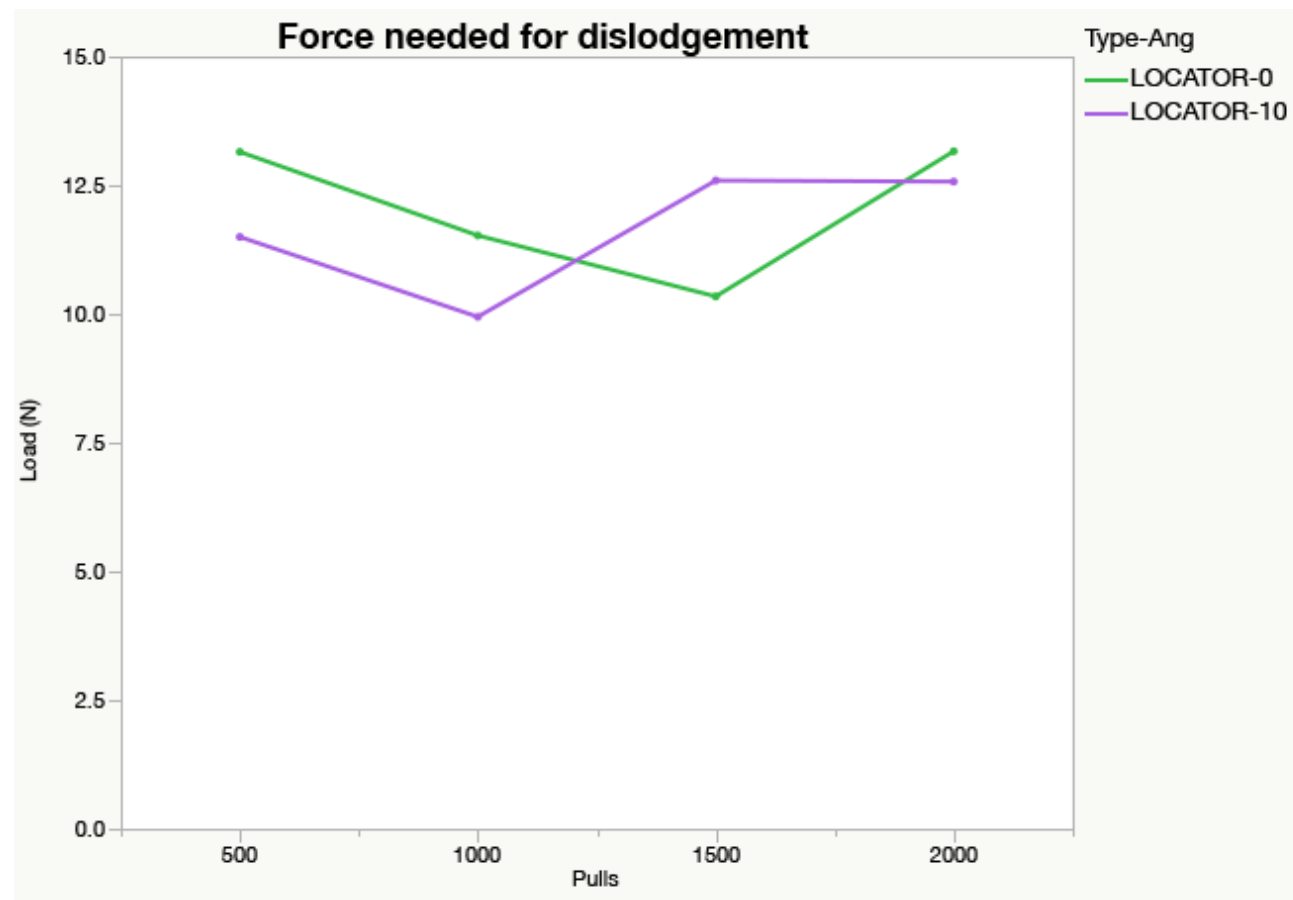

Figure 10-B. Means force of dislodgment of LOCATOR sample group (JMP/Pro Ver12, SAS Inst. Inc., Cary, NC).

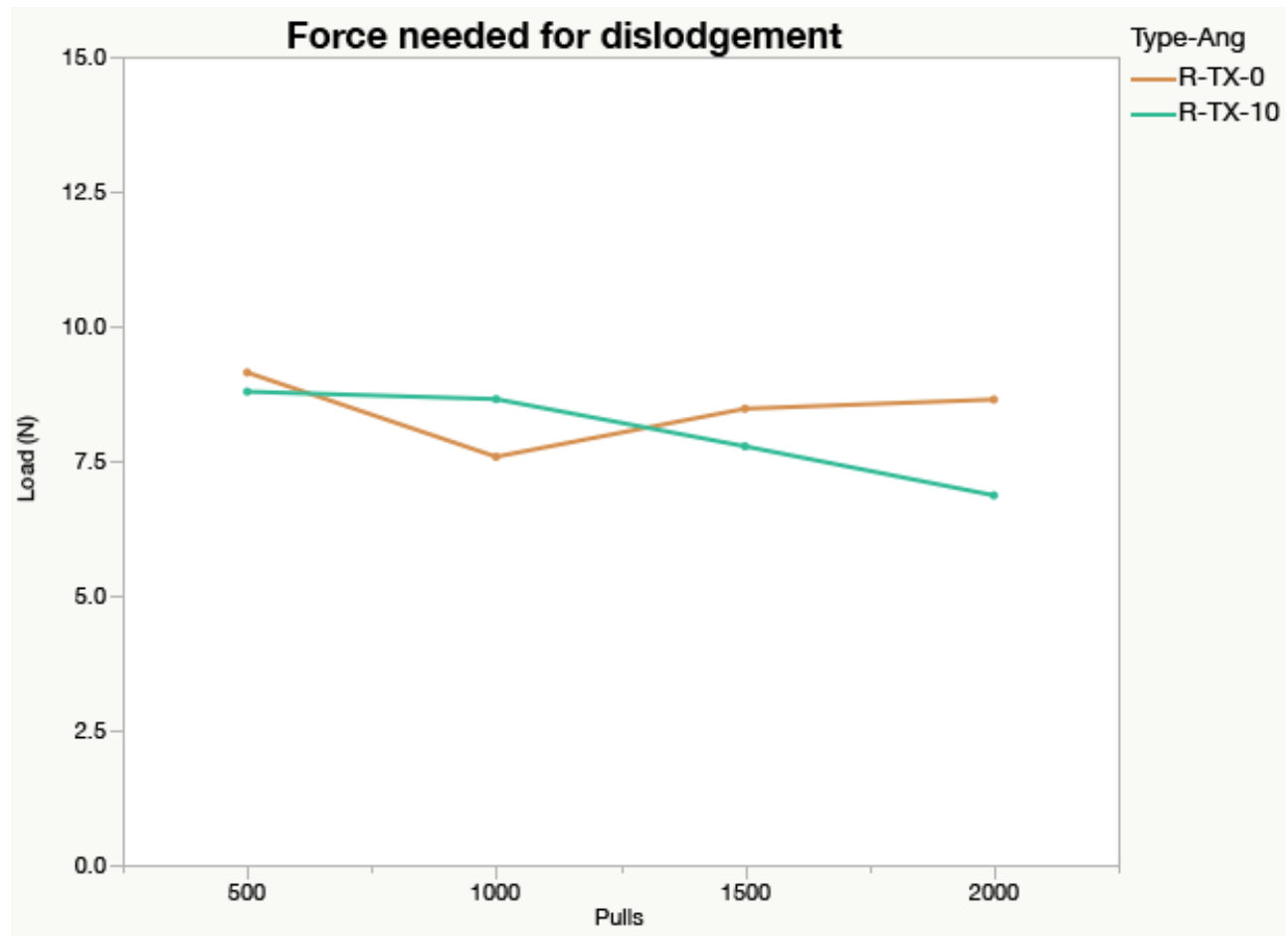

Figure 10-C. Means force of dislodgment of locator R-TX sample group (JMP/Pro Ver12, SAS Inst. Inc., Cary, NC). 


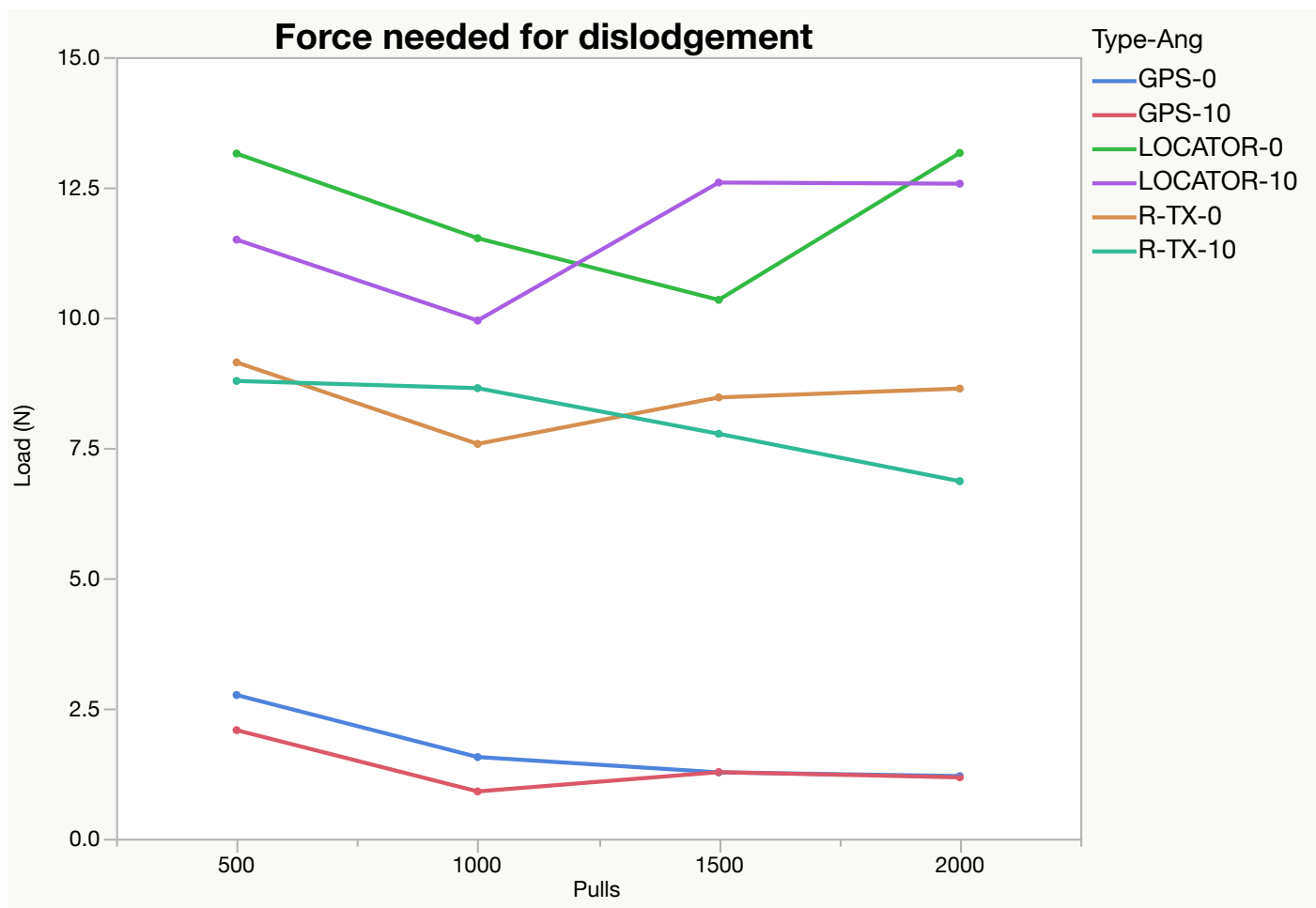

Figure 11. Means force for dislodgment of all sample groups (JMP/Pro Ver12, SAS Inst. Inc., Cary, $\mathrm{NC}$ )

Table 1. Means force for dislodgment of all sample groups and standard deviation in Newton.

\begin{tabular}{|l|l|l|l|l|}
\hline ATTACHMENT & PULL 500 & PULL 1000 & PULL 1500 & PULL 2000 \\
\hline GPS-0 & $2.76 \pm 2.09$ & $1.57 \pm 1.22$ & $1.27 \pm 0.99$ & $1.20 \pm 0.73$ \\
\hline GPS-10 & $2.08 \pm 0.84$ & $0.91 \pm 0.84$ & $1.28 \pm 0.94$ & $1.18 \pm 0.99$ \\
\hline LOCATOR-0 & $13.15 \pm 6.87$ & $11.52 \pm 5.24$ & $10.34 \pm 5.15$ & $13.16 \pm 6.76$ \\
\hline LOCATOR-10 & $11.50 \pm 6.87$ & $9.94 \pm 4.65$ & $12.59 \pm 5.28$ & $12.57 \pm 4.44$ \\
\hline R-TX-0 & $9.14 \pm 5.80$ & $7.58 \pm 4.85$ & $8.47 \pm 5.65$ & $8.64 \pm 6.95$ \\
\hline R-TX-10 & $8.78 \pm 7.67$ & $8.65 \pm 8.88$ & $7.77 \pm 8.67$ & $6.86 \pm 5.60$ \\
\hline
\end{tabular}


An analysis of variance compared all the groups as a whole. When a test with random effects compared the interactions of the data, the only interaction that was significant is the type of the attachment $(p$-value $=0.0002)$. Neither the number of pulls nor the inter-implants angulation were significant as shown in (Table 2).

Table 2. Mixed Effects ANOVA.

\begin{tabular}{|l|r|r|r|r|r|}
\hline Variables & Nparm & DF & DFDen & F Ratio & Prob > F \\
\hline Attachment & 2 & 2 & 26 & 12.4086 & $\mathbf{0 . 0 0 0 2}^{\mathrm{a}}$ \\
\hline Angle & 1 & 1 & 26 & 0.0518 & 0.8218 \\
\hline Pull & 3 & 3 & 87 & 1.8456 & 0.1449 \\
\hline
\end{tabular}

${ }^{\mathrm{a}}$ Represents significant differences at the $\mathrm{P}<0.05$ interval (JMP/Pro Ver12, SAS Inst. Inc., Cary, NC).

The least square means were calculated by the type of attachment (Table 3), number of pulls (Table 4), inter-implants angulation (Table 5) and interactions between these variables. The p-value for the type of attachment was 0.0002 making the attachment a significant variable. The p-value for the number of pulls was 0.1449 and the p-value for the angle was 0.8218 making both of these not significant.

Table 3. Least Squares Means by type of Attachment.

\begin{tabular}{|l|r|r|}
\hline Variables & $\begin{array}{r}\text { Least Squares } \\
\text { Means(2000 } \\
\text { Pulls) }\end{array}$ & \\
\hline GPS & 1.529250 & 1.4862702 \\
\hline LOCATOR & 11.846750 & 1.4862702 \\
\hline R-TX & 8.235250 & 1.4862702 \\
\hline
\end{tabular}


Table 4. Least Squares Means by number of pulls.

\begin{tabular}{|l|r|r|}
\hline Variables & $\begin{array}{r}\text { Least Squares } \\
\text { Means }\end{array}$ & Study Error \\
\hline 500 & 7.9010000 & 0.92005261 \\
\hline 1000 & 6.6936667 & 0.92005261 \\
\hline 1500 & 6.9530000 & 0.92005261 \\
\hline 2000 & 7.2673333 & 0.92005261 \\
\hline
\end{tabular}

Table 5. Least Squares Means by inter-implants angulation.

\begin{tabular}{|l|r|r|}
\hline Variables & $\begin{array}{r}\text { Least Squares } \\
\text { Means }\end{array}$ & Study Error \\
\hline $0^{\circ}$ & 7.3990000 & 1.2135345 \\
\hline $10^{\circ}$ & 7.0085000 & 1.2135345 \\
\hline
\end{tabular}

When comparing the data as a whole by attachment type, after 2000 pulls the mean force needed to dislodge the GPS attachment was $1.529 \mathrm{~N}$. The Locator attachment was 11.847 $\mathrm{N}$ while for Locator R-TX 8.235 $\mathrm{N}$ as shown in (Table 3). To define the significant differences within the type of the attachment used, a Tukey-Kramer HSD was completed (Table 6). A significant difference was noticed between GPS and the other two systems used. The p-values are as follows: GPS vs. Locator $\mathrm{p}=0.0001$, GPS vs. Locator R-TX $p=$ 0.0037, while Locator vs. Locator R-TX p $=0.0976$ (not significant).

Table 6. Tukey-Kramer HSD defining significant differences within the type of the attachment.

\begin{tabular}{|llr|}
\hline Attachment & & $\begin{array}{r}\text { Least Sq Mean Rate } \\
\text { (Newton) }\end{array}$ \\
\hline LOCATOR & A & 11.846750 \\
\hline R-TX & A & 8.235250 \\
\hline GPS & B & 1.529250 \\
\hline
\end{tabular}

Attachments not connected by the same letter showed significant differences (JMP/Pro Ver12, SAS Inst. Inc., Cary, NC). 
The Comparison was made between the initial retention force (pull 500) and the final retention force (pull 2000) and the loss of retention was summarized in (Table 7).

Table 7. The initial and final retention for the sample groups.

\begin{tabular}{|l|l|l|l|l|}
\hline \multicolumn{5}{|c|}{ Comparison of pull 500 to pull 2000 for each sample group } \\
\hline & Pull $500(N)$ & Pull 2000 (N) & $\begin{array}{l}\text { Lost retention } \\
(\mathbf{N})\end{array}$ & $\begin{array}{l}\text { Lost retention } \\
(\%)\end{array}$ \\
\hline GPS 0 & 2.76 & 1.20 & 1.56 & $56.52 \%$ \\
\hline GPS 10 & 2.08 & 1.18 & 0.9 & $43.27 \%$ \\
\hline LOCATOR 0 & 13.15 & 13.16 & +0.01 & $+0.08 \%$ \\
\hline LOCATOR 10 & 11.50 & 12.57 & +1.07 & $+9.30 \%$ \\
\hline R-TX 0 & 9.14 & 8.64 & 0.5 & $5.47 \%$ \\
\hline R-TX 10 & 8.78 & 6.86 & 1.92 & $21.87 \%$ \\
\hline
\end{tabular}




\section{Chapter V}

\section{DISCUSSION}

The present study investigated the dislodging forces necessary to separate acrylic blocks modeling a mandibular overdenture that attached to two implants by the GPS, Locator or Locator R-TX dental implant attachment systems. Based on the results, the null hypothesis that there would be no significant difference in the retention of the Locator R-TX, Locator and GPS attachment systems on parallel and divergent implants was rejected. All the attachments, except for Locators, lost retention. A significant difference was seen between the GPS attachment and the two other attachment systems used in the study.

A total of 30 blocks were seated and unseated by hand 2000 times to develop the wear patterns of the liners in more of a clinically relevant manner. To better simulate deviations from ideal, implants were positioned in parallel or had a total inter-implants divergence of 10 degrees. The Locator attachment showed the highest mean force of dislodgement of $11.847 \mathrm{~N}$, followed by Locator R-TX $8.235 \mathrm{~N}$, then $1.529 \mathrm{~N}$ for the GPS. This would suggest that clinically, the Locator would have significantly more retention in all instances where the implants had 10 degrees of divergence or less. This is in agreement with the manufacturer's recommendation for the use of these attachment systems.

There does not seem to be a difference within each system with respect of how they perform on parallel or angled implants (Table 5). This would suggest that all systems accommodate angled implants to a similar degree. The mean for the 0 degrees angulation was $7.399 \mathrm{~N}$ while for the 10 degrees inter-implants divergence angulation the mean was $7.008 \mathrm{~N}$. Neither of these observations was statistically significant.

Interactions involving number of pulls didn't show statistical significance. The means were as follows: pull $500=7.901 \mathrm{~N}$, pull $1000=6.694 \mathrm{~N}$, pull $1500=6.953 \mathrm{~N}$ and for pull $2000=7.267 \mathrm{~N}$. Regardless of the attachment and inter-implant angulation, the majority of retention loss occurred in the pulls 500-1000 with the exception of locator R- 
TX with 10 degrees inter-implants angulation had the major loss of retention after pull 1000 (Figure 11). This plot shows that both the GPS system and the Locator system lose a significant amount of its initial retention while the Locator R-TX stays at a fairly consistent level. Even though the Locator has higher initial retention, it quickly falls between pulls 500-1000 and then starts gaining retention. Clinically, the Locator system may provide the clinician with an attachment that retains most of its initial retention over 2000 cycles of seating and unseating.

The comparisons of the means of pull 500 and pull 2000 for each sample group can be seen in (Table 7). Over $50 \%$ of the initial retention of the GPS system on parallel implants was lost by pull 2000 and about $43 \%$ on angled implants. The Locator R-TX on angled implants lost about $22 \%$ of its initial retention and on parallel implants about $5 \%$ of retention over the course of the test. The Locator attachment system gained retention about $0.1 \%$ and $9 \%$ in parallel and angled implants respectively. This gain is not statistically significant.

Stephens et al ${ }^{10}$ did a study to assess the influence of inter-implant divergence on retention of two Locator attachments before and after in vitro simulation of 3 to 5 years of use. Ten pairs of Locators were tested with inter-implant divergences of 0 degrees, 10 degrees, and 20 degrees. At the start of the experiment, the 10 degrees group showed significantly more retention than the 0 degrees group, but no significant difference was found between the 0 degrees and 20 degrees groups or the 10 degrees and 20 degrees groups. After 5500 cycles, there was no significant difference in retention between any of the groups.

Yang $e \mathrm{al}^{47}$ did a study to evaluate the retentive force and lateral force placed on an implant with various types of attachments for overdentures in relation to implant inclination. The retentive capacity of the blue locator insert was tested on implants with an angle of 0 degrees, 15 degrees, 30 degrees, and 45 degrees. At 0 degrees, the significantly highest retentive force was observed in the Locator with blue insert. The results of the current study showed about $2 \mathrm{~N}$ less retention on the parallel Locators when 
compared with the Yang et. al. ${ }^{47}$ study.

Al-Ghafli et. al. ${ }^{48}$ surmised that overdenture wearers inserted and removed their overdentures four times per day: Insert at morning, remove and insert after breakfast, lunch and dinner the remove before bedtime. Following this hypothetical usage pattern, the 2000 cycles in this study would have roughly simulated sixteen months of use. An advantage of this study's protocol was that attachment seating and unseating was performed by hand, which could influence the wear patterns of the liners in a more clinical relevant manner as described in other studies. ${ }^{10}$ To better simulate deviations from ideal the implants were either positioned ideally in parallel or had an inter-implant divergence of 10 degrees.

One of limits of this study is lack of a salivary substitute, which is necessary to attain relevant results from wear studies. ${ }^{46}$ Temperature may also be important to Locator wear behavior, because of the low glass transition temperature of the nylon used in the patrix insert. ${ }^{9}$ The laboratory offers an environment in which a single variable can be studied in isolation, including those which may be difficult or impossible to measure in the clinical situation. Another limitation in the current study is the use of abutment analogs instead of the abutment attachment. The difference in the material between the actual abutment and the laboratory analogs my have an effect on the rate and the pattern of wear of the nylon inserts of the attachment systems.

The increase in retentive forces of Locator attachments after 2000 pulls is a curious finding that falls outside of the expected behavior. Further investigation is required to determine the potential cause of these findings. In addition, future studies in an aqueous environment should be performed to simulate a more clinical relevant situation and to determine the wear pattern of the different attachment systems used to retain overdentures. 
Since the majority of the retention lost occurred in the initial cycles, practitioners might need to bring overdenture wearers back one month after insertion and then every three months to evaluate the inserts and their satisfactions with retention of the overdenture. 


\section{Chapter VI:}

\section{SUMMARY}

The implant-retained overdenture is a very successful alternative treatment modality for edentulous patients, especially in the mandible. The presence of a wide range of implant attachment systems should improve and facilitate the expected outcome. Clinically an attachment that maintains its retention for an extended period of time could lead to less overdenture maintenance and possible greater patient satisfaction. This study demonstrated that regardless of whether the implants were placed in parallel position or within 10 degrees of divergence, the clinician should feel confident that retentive overdenture prosthesis could be fabricated.

\section{CONCLUSIONS}

1) The Locator attachment retains its retentive properties much better over 2000 cycles of seating and unseating.

2) The Locator preformed better than GPS and Locator R-TX attachment systems on two implants that were parallel or had 10 degrees of divergence.

3) 10 degrees of Inter-implants angulation didn't have deleterious effect on retentive properties of the attachments. 


\section{REFERENCES}

1. Feine JS, Carlsson GE, Awad MA, et al. The McGill consensus statement on overdentures. mandibular two-implant overdentures as first choice standard of care for edentulous patients. Gerodontology. 2002;19(1):3-4.

2. Thomason JM. The McGill Consensus Statement on Overdentures. Mandibular 2Implant overdentures as first choice standard of care for edentulous patients. The European Journal of Prosthodontics and Restorative Dentistry. 2002; 10(3):95-96.

3. Lee CK, Agar JR. Surgical and prosthetic planning for a two-implant-retained mandibular overdenture: A clinical report. J Prosthet Dent. 2006;95(2):102-105.

4. Van Kampen F, Cune M, van der Bilt A, Bosman F. Retention and post-insertion maintenance of bar-clip, ball and magnet attachments in mandibular implant overdenture treatment: an in vivo comparison after 3 months of function. Clin Oral Implants Res 2003;14:720-6.

5. MacEntree MI, Walton JN, Glick N. A clinical trial of patient satisfaction and prosthodontic needs with ball and bar attachments for implant-retained complete overdentures: three-year results. J Prosthet Dent 2005;93:28-37.

6. Naert I, Alsaadi G, Quirynen M. Prosthetic aspects and patient satisfaction with twoimplant-retained mandibular overdentures: a 10-year randomized clinical study. Int J Prosthodont 2004;17:401-10.

7. Gotfredsen K, Holm B. Implant-supported mandibular overdentures retained with ball or bar attachments: a randomized prospective 5-year study. Int J Prosthodont 2000;12:125-30.

8. The glossary of prosthodontic terms. J Prosthet Dent. 2005;94(1):10-92. 
9. Alsabeeha NHM, Payne AGT, Swain MV: Attachment systems for mandibular twoimplant overdentures: a review of in vitro investigations on retention and wear features. Int J Prosthodont 2009;22:429-440.

10. Stephens GJ, di Vitale N, O'Sullivan E, McDonald A. The influence of inter-implant divergence on the retention characteristics of locator attachments, a laboratory study. Journal of Prosthodontics. 2014;23(6):467-475.

11. Trakas T, Michalakis K, Kang K, et al: Attachment systems for implant-retained overdentures: a literature review. Implant Dent 2006;15:24-34.

12. Rutkunas V, Mizutani H, Takahashi H: Influence of attachment wear on retention of mandibular overdenture. J Oral Rehabil 2007;34:41-51.

13. Nguyen CT, Masri R, Driscoll CF, et al: The effect of denture cleansing solutions on the retention of pink Locator attachments: an in vitro study. J Prosthodont 2010;19:226-230.

14. Fenton AH. The decade of overdentures: 1970-1980. J Prosthet Dent.1998;79(1):3136.

15. Tallgren A. Changes in adult face height due to aging, wear, loss of teeth, and prosthetic treatment. Acta Odontol Scand 1957;15 Suppl:24.

16. Atwood DA, Coy WA. Clinical, cephalometric, and densitometric study of reduction of residual ridges. J Prosthet Dent 1971;26:280-5.

17. Brill N. Adaptation and the hybrid prosthesis. J Prosthet Dent 1955;5:811-23.

18. Prince JB. Conservation of the supportive mechanism. J Prosthet Dent 1965;19:32738. 
19. Morrow RM, Feldmann EE, Rudd KD, Trovillion HM. Tooth-supported com-plete dentures: an approach to preventive prosthodontics. J Prosthet Dent 1969;21:513-22.

20. Lord JL, Teel S. The overdenture. Dent Clin North Am 1969;13:871-81.

21. Carl E. Misch, Dental Implant Prosthetics (second edition), ISBN: 978-0-323-078450.

22. Laney WR, Tolman DE, Keller EE, et al: Dental implants: Tissue-integrated prosthesis utilizing the osseointegration concept. Mayo Clin Proc 1986;61:91-97.

23. Albrektsson $\mathrm{T}$, Zarb G, Worthington $\mathrm{P}$, et al: The long term efficacy of currently used dental implants: A review and proposed criteria of success. Int J Oral Maxillofac Implants 1986;1:11-24.

24. Adell R, Lekholm U, Rockler B, et al: A 15-year study of osseointegrated implants in the treatment of the edentulous jaw. Int J Oral Surg 1981;10:387-416.

25. Mericske-Stern R: Clinical evaluation of overdenture restorations supported by osseointegrated titanium implants: a retrospective study. Int J Oral Maxillofac Implants 1990;5:375-383.

26. Zarb GA, Schmitt A: The edentulous predicament. II: the longitudinal effectiveness of implant-supported overdentures. J Am Dent Assoc 1996;127:66-72.

27. Strassburger C, Kerschbaum T, Heydecke G: Influence of implant and conventional prostheses on satisfaction and quality of life: a literature review. Part 2: qualitative analysis and evaluation of the studies. Int J Prosthodont 2006;19:339-348. 
28. Van der Bilt A, Burgers M, VanKampen FMC, et al: Mandibular implant-supported overdentures and oral function. Clin Oral Implants Res 2010;21:1209-1213.

29. Yamada R, Gorin D, Marinello R, Rosen M, Russo S. Implant-supported overdentures: The standard of care for edentulous patients. The Periodontics Ltd. 2006.

30. Schwartz-Arad D, Kidron N, Dolev E. A long-term study of implants supporting overdentures as a model for implant success. Journal of Periodontology. 2005;76(9): 1431-1435.

31. Caldwell RC. Adhesion of foods to teeth. J Dent Res 1962;41:821-32.

32. Walmsley AD, Frame JW. Implant supported overdentures the Birmingham experience. J Dent 1997; 25 Suppl 1:S43-7.

33. Walmsley AD. Magnetic retention in prosthetic dentistry. Dent Update 2002;29:42833.

34. Petropoulos VC, Smith W. Maximum dis-lodging forces of implant overdenture stud attachments. Int J Oral Maxillofac Implants 2002;17:526-35.

35. Gamborena JI, Hazelton LR, NaBadalung D, Brudvik J. Retention of ERA direct overdenture attachments before and after fatigue loading. Int J Prosthodont 1997;10:123-30.

36. Setz I, Lee SH, Engel E. Retention of prefabricated attachments for implant stabilized overdentures in the edentulous mandible: an in vitro study. J Prosthet Dent 1998;80:323-9.

37. Stewart BL, Edwards RO. Retention and wear of precision-type attachments. J Prosthet Dent 1983;49:28-34. 
38. Duyck J, Van Oosterwyck H, Vander Sloten J, De Cooman M, Puers R, In vivo forces on oral implants supporting a mandibular overdenture: the influence of attachment system. Clin Oral Investig.1999 Dec;3(4):201-7.

39. Sadowsky S: Mandibular implant-retained overdentures: A literature review, J Prosthet Dent 2001;86:468-73.

40. Nedir R, BischofM, Szmukler-Moncler S, Belser UC, Samson J. Prosthetic complications with dental implants: from an up-to-8-year experience in private practice. The International Journal of Oral \& Maxillofacial Implants. 2006;21 ( 6):919-928.

41. Andreiotelli M, Att W, Strub J-R: Prosthodontic complications with implant overdentures: a systematic literature review. Int J Prosthodont 2010;23:195-203.

42. Stoumpis C, Kohal R-J: To splint or not to splint oral implants in the implantsupported overdenture therapy? A systematic literature review. J Oral Rehabilitation 2011;38:857-869.

43. Cehreli MC, Karasoy D, Kokat AM, et al: Systematic review of prosthetic maintenance requirements for implant-supported overdentures. Int J Oral Maxillofacial Implants 2010;25:163-80.

44. Ahuja S, Cagna DR. Defining available restorative space for implant overdentures. J Prosthet Dent. 2010;104(2):133-136.

45. Wine, C. H. Retentive Comparison of Overdenture Attachment Systems on Straight and Divergent Dental Implants. West Virginia University, ProQuest Dissertations Publishing, 2015. 1588161. 
46. Bayer S, Keilig L, Kraus D, et al: Influence of the lubricant and the alloy on the wear behaviour of attachments. Gerodontology 2011;28:221-22650. Libby G, Arcuri MR, LaVelle WE, Hebl L. Longevity of fixed partial dentures. J Prosthet Dent. 1997;78(2):127-131. doi: S0022-3913(97)70115-X [pii].

47. Yang T-C, Maeda Y, Gonda T, et al: Attachment systems for implant overdenture: influence of implant inclination on retentive and lateral forces. Clin Oral Implants Res 2011;22:1315-1319.

48. Al-Ghafli SA, Michalakis KX, Hirayama H, Kang K. The in vitro effect of different implant angulations and cyclic dislodgement on the retentive properties of an overdenture attachment system. J Prosthet Dent. 2009;102(3):140-147.

49. Mericske-Stern R. Treatment outcomes with implant-supported overdentures: clinical considerations. J Prosthet Dent 1998;79:66-73.

50. Wismeijer D, Van Waas MA, Vermeeren JI, Mulder J, Kalk W. Patient satisfaction with implant-supported mandibular overdentures. A comparison of three treatment strategies with ITI-dental implants. Int J Oral Maxillofac Surg. 1997 Aug;26(4):2637.

51. Moustafa Abdou ELsyad, Hatem Mokhtar Errabti, Aisha Zakaria Mustafa. Mandibular Denture Base Deformation with Locator and Ball Attachments of Implant-Retained Overdentures. Journal of Prosthodontics (2016) doi: 10.1111/jopr.12356.

52. Brånemark P, Zarb GA, Albrektsson T (eds): Tissue Inte-grated Prosthesis (ed 1). Chicago, IL, Quintessence, 1985, pp 211-232.

53. Alsabeeha NHM, Swain MV, Payne AGT: Clinical performance and material properties of single-implant overdenture attachment systems. Int J Prosthodont $2011 ; 24: 247-254$. 
54. Rahn AO, Heartwell CM. Complete denture impressions. In: Textbook of complete dentures. ; 1993:227.

55. Zitsmann NU, Marinello CP: Decision-making and treatment planning in the edentulous mandible restored with fixed or removable implant prostheses. World Dent 2001;1, available at www.worlddent.com (Accessed in 2011)

56. Carlsson GE. Changes in the jaws and facial profile after extractions and prosthetic treatment. Stockholm and Umea Series. Trans R Schools Dent 1967;2:12.

57. Thomason JM, Heydecke G, Feine JS, et al: How do patients perceive the benefit of reconstructive dentistry with regard to oral health-related quality of life and patient satisfaction? A systematic review. Clin Oral Implants Res 2007;18:(Suppl 3):168188.

58. Rosenstiel L, Fujimoto. Contemporary fixed prosthodontics. 4th ed. St. Louis, Missouri: Rudolph, Penny; 2006.

59. Ledger E. On preparing the mouth for the reception of a full set of artificial teeth. Br J Dent Sci 1856;1:90.

60. Atkinson WH. Plates over fangs. Dent Reg 1861;15:213-6.

61. Burns DR. Mandibular implant overdenture treatment: Consensus and controversy. Journal of Prosthodontics. 2000;9(1):37-46.

62. Miller PA. Complete dentures supported by natural teeth. J Prosthet Dent 1958;8:924-8. 
63. Zarb GA, Bolender CL, Eckert SE, Boucher CO. Prosthodontic treatment for edentulous patients: Complete dentures and implant-supported prostheses. St. Louis: Mosby; 2004.

64. Fueki K, Kimoto K, Ogawa T, et al. Effect of implant-supported or retained dentures on masticatory performance: a systematic review. The Journal of Prosthetic Dentistry. 2007;98(6):470-477

65. Emami E, Heydecke G, Rompr'e PH, et al: Impact of implant support for mandibular dentures on satisfaction, oral and general health-related quality of life: a metaanalysis of randomized-controlled trials. Clin Oral Implants Res 2009;20:533-544.

66. Dias R, Moghadam M, Kuyinu E, Jahangiri L. Patient satisfaction survey of mandibular two-implant-retained overdentures in a predoctoral program. J Prosthet Dent. 2013;110(2):76-81.

67. Regina Mericske- Stern, Overdentures with roots or implants for elderly patients: A comparison. (J PROSTHET DENT 1994;72:543-50.). 


\section{Curriculum Vitae}

Khalid A. Azzouz, D.D.S.

115 Meadow Ridge Townhomes, Morgantown, WV 26505

(614) 260-5692

kaazzouz@mix.wvu.edu

\section{EDUCATION}

West Virginia University, Morgantown, WV

[M.S. in Prosthodontics]- expected graduation May 2017

2014-Present

The Ohio State University, Columbus, $\mathrm{OH}$

General Practice residency

2010-2012

New York University, New York, NY

Oral Medicine and Special Needs Dentistry

2009-2010

Tripoli University, Tripoli, Libya

Doctor of Dental Surgery

Dean's honor list

1997-2003

\section{Licensure}

West Virginia Board of Dentistry

2014-Present

\section{MEMBERSHIPS}

American College of Prosthodontists

Academy of Osseointegration

\section{LANGUAGES}

[English/ Arabic] 